\title{
Fiscal and Monetary Nexus in Emerging Market Economies: How Does Debt Matter?
}

Taimur Baig, Manmohan S. Kumar, Garima Vasishtha, and Edda Zoli 



\title{
IMF Working Paper
}

Fiscal Affairs Department

Fiscal and Monetary Nexus in Emerging Market Economies: How Does Debt Matter?

Prepared by Taimur Baig, Manmohan S. Kumar, Garima Vasishtha, and Edda Zoli ${ }^{1}$

August 2006

\begin{abstract}
This Working Paper should not be reported as representing the views of the IMF. The views expressed in this Working Paper are those of the author(s) and do not necessarily represent those of the IMF or IMF policy. Working Papers describe research in progress by the author(s) and are published to elicit comments and to further debate.

This paper examines two main aspects of the interaction between fiscal and monetary policy in emerging market economies. First, it explores the interest rate-inflation relationship in economies with different levels of external and domestic public debt using panel- and crosssection data. The results show that interest rate-inflation elasticity weakens with debt/GDP and external debt/GDP. Second, it utilizes high-frequency data from Brazil, Turkey, and Poland to examine how market-determined variables react to economic news. The results suggest that when vulnerabilities are high, budget news has the most significant impact on country spreads and interest rates, and the impact of monetary policy is weakened.
\end{abstract}

JEL Classification Numbers: H63, H30, E5

Keywords: Public Debt, Fiscal Policy, Monetary Policy

Author(s) E-Mail Address: tbaig@imf.org, mkumar@imf.org, ezoli@imf.org, garimav@ucsc.edu

\footnotetext{
${ }^{1}$ Messrs. Baig and Kumar are in the IMF's Fiscal Affairs Department; Ms. Vasishtha is at the University of California at Santa Cruz; and Ms. Zoli is in the IMF's European Department (she was at the IMF Institute when she worked on this paper). The authors thank Xavier Debrun, Evan Turner, and participants at the paper's presentation at an FAD seminar for useful comments.
} 


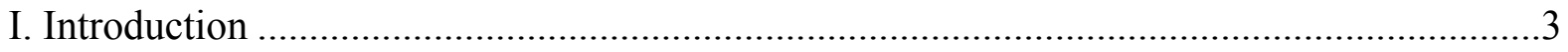

II. Fiscal-Monetary Nexus: Analytical and Empirical Studies .............................................5

A. Government Budget Constraint, Monetary Policy, and Fiscal Theory of Price

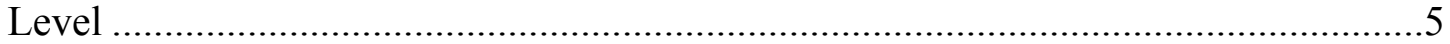

B. Impact of Fiscal Policy on Sovereign Spreads, Interest Rates, and Exchange Rates6

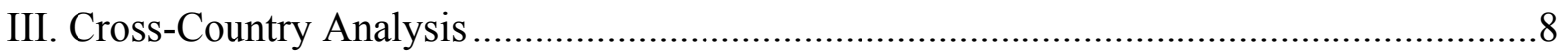

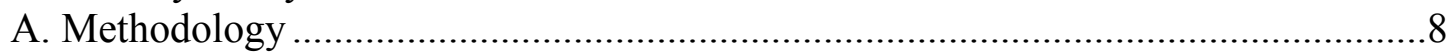

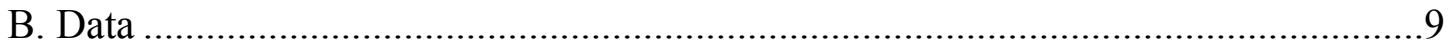

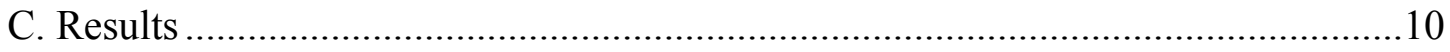

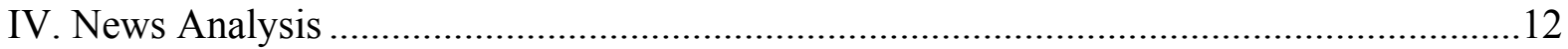

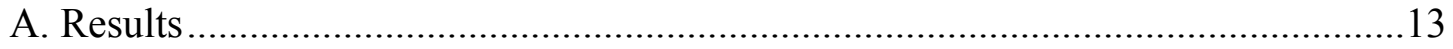

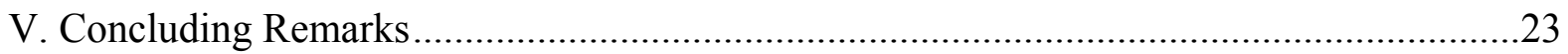

Tables

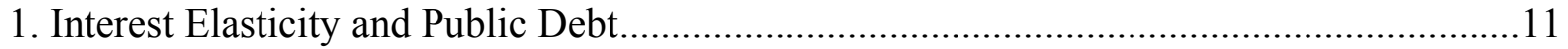

2. Impact of News on Spreads, Interest Rate, and Exchange Rate in Brazil, 2002-2004 .......16

3. Impact of News on Spreads, Interest Rate, and Exchange Rate in Poland, 2002-2004 ......18

4. Impact of News on Spreads, Interest Rate, and Exchange Rate in Turkey, 2001-2002 .....20

5. Impact of News on Spreads, Interest Rate, and Exchange Rate in Turkey, 2001-2004 .....22

Figures

1. Impulse Response Functions for Brazil .....................................................................24

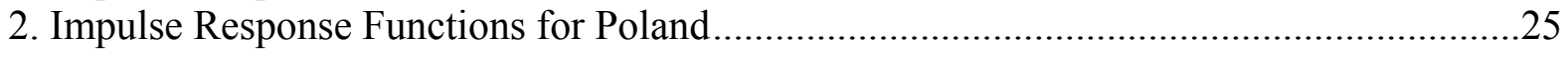

3. Impulse Response Functions for Turkey, 2001-2004 ..................................................26

Appendixes

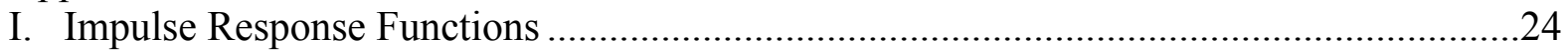

II. Variable Definitions and Data Sources for News Analysis .........................................27

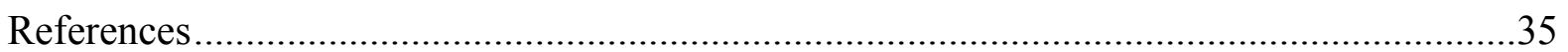




\section{INTRODUCTION}

The macroeconomic costs of increased public indebtedness are well known and relatively uncontroversial. ${ }^{2}$ Concerns about fiscal sustainability and a possible financial crisis in the context of increasing indebtedness, for example, can create an adverse cycle of higher borrowing costs and worsening fiscal balances. As debt and debt payments increase, the fiscal space available for other expenditures is correspondingly squeezed. High levels of public debt can also impede economic growth as the government crowds out private sector borrowing because of its own financing needs.

There has been an increasing emphasis on recent years on the macroeconomic policy costs of debt. Monetary policy, for instance, could be constrained by the government's budgetary position and the conduct of fiscal policy itself. The concept of "fiscal dominance," in particular, has received considerable attention in both policy and academic circles: ${ }^{3}$ a key aspect of this concerns the compatibility of a given monetary policy stance with a particular fiscal stance. A specific issue in this area has been regarding when and how monetary authorities may need to compensate for an overly expansionary fiscal policy.

This issue of an appropriate policy mix or the constraints that a particular fiscal policy stance could impose on monetary authorities long predates the relatively recent moves toward central bank independence. What is more recent, however, is the recognition that despite the independence of monetary authorities, fiscal policy actions set the environment in which monetary policy may be strongly influenced and even severely constrained. As has been well recognized, even where the monetary authorities can offset developments on the fiscal front, the resultant policy mix can have significant implications for financial markets and the real economy, including the term structure of interest rates, exchange rates, and inflationary expectations.

Such policy constraints are seen both in industrial and developing economies. For instance, in both sets of countries, in an environment of weak economic activity, large or rising budget deficits are often cited as constraining monetary authorities' ability to implement accommodative monetary policy. In an environment of robust activity, expansionary fiscal policy has been rightly seen to increase the need for a tight monetary policy. ${ }^{4}$ In addition to the constraints on monetary policy imposed by the stance of fiscal policy, it is increasingly recognized that the impact of past fiscal decisions, or of budgetary developments generally, can also play an important role. To the extent that this may then constrain the conduct of monetary policy, a key instrument for stabilization may cease to be available. In cases where

\footnotetext{
${ }^{2}$ See IMF (2003) for a more detailed discussion on this issue.

${ }^{3}$ There is considerable theoretical and empirical literature in this area: for an analysis of fiscal dominance in industrial countries, see, for instance, Fratanni and Spinelli (2001), and Rogoff (2003); for issues relating to emerging markets, the focus of this paper, see Tanner and Ramos (2003) and Blanchard (2004).

${ }^{4}$ In the United States, for instance, then Chairman of the Federal Reserve Alan Greenspan's pronouncements that an unduly expansionary fiscal policy would constrain the conduct of monetary policy is notable (see Greenspan, 2004a, and 2004b).
} 
fiscal policy is, in any case, constrained, this can impose severe limitations on the ability of the policymakers to offset the impact of shocks or to implement stabilization policy.

The circumstances under which monetary policy can be constrained can be illustrated readily: consider an essentially closed economy, with a large outstanding stock of government debt held by domestic private agents. ${ }^{5}$ In such an economy, an increase in inflation or inflationary expectations, would warrant a tightening of monetary policy. But an increase in policy rates will raise long-term rates via the term structure, increasing debtservicing costs. The larger the debt, ceteris paribus, the greater would be the impact. ${ }^{6}$ In situations such as this one, the fiscal authorities have been seen to urge monetary authorities to tighten policy less than warranted, even though rising inflationary expectations would have led to an increase in the long-term nominal interest rates in any case. Indeed, tightening of monetary policy could help in lowering inflationary expectations and flattening the yield curve.

The paper's main objective is to explore a number of issues relating to the type of constraints facing monetary authorities noted above. For instance, does the relationship between interest rate and inflation change as the level of public debt rises? Or under what circumstances can unanticipated developments (i.e., "news") about the fiscal situation "dominate" monetary policy measures? The paper examines these issue using two approaches. First, it uses quarterly data for a set of 25 emerging markets to evaluate the response of monetary policy to inflation as the level of debt varies. Second, it undertakes a higher-frequency news analysis to assess the impact of fiscal and other macroeconomic news on sovereign spreads, interest rates, and exchange rates in three major emerging markets, namely Poland, Turkey, and Brazil.

The discussion is organized as follows: Section II briefly summarizes the existing literature; Section III evaluates whether the response of monetary policy to inflation depends on the level of debt in a cross-country framework; Section IV presents an event study assessing the impact of fiscal and other macroeconomic news on sovereign spreads, interest rates, and exchange rates in three emerging markets. Section $\mathrm{V}$ provides concluding remarks.

\footnotetext{
${ }^{5}$ Assuming that all debt is denominated in domestic currency and is not indexed.

${ }^{6}$ Given the short-to-medium maturities (say $1-5$ years), higher rates will have to be paid on refinancing. Even if maturities were long, primary market new issuance would carry higher interest rates.
} 


\section{FisCal-Monetary NeXUS: ANALYTICAL AND EMPIRICAL STUDIES}

There are a number of well-identified channels through which fiscal policy can affect monetary policy. The most direct connection is through the government budget constraint, which can be reflected in recourse to central bank financing of deficits, and on central bank credibility, and inflation and inflationary expectations. Inflation will also be affected more directly by the impact of fiscal policy on aggregate demand. Indeed, recent models of the 'fiscal theory of the price level' suggest that fiscal policy can be the main determinant of inflation. Budgetary actions will also have a bearing on monetary policy by having a direct impact on interest rates, interest spreads and exchange rates. ${ }^{7}$

\section{A. Government Budget Constraint, Monetary Policy, and Fiscal Theory of Price Level}

Sargent and Wallace (1981) first formally highlighted the monetary policy implications of the government budget constraint. They describe the case of fiscal dominance, under which the fiscal authority determines the financing needed for any given budget deficit through bond sales and seigniorage, and the monetary authority loses its ability to control inflation whenever the real interest rate exceeds the growth rate of the economy. If, for instance, high government deficits and debt raise the real interest rate to a level above the growth rate of the economy, monetary actions aimed at reducing inflation will increase the ratio of debt to GDP, as bond finance replaces monetary finance. This in turn raises interest payments and deficits in the future. Eventually deficit financing requires more money growth and generates higher inflation in the future. ${ }^{8}$ In such a situation, lower debt-if it reduces the real interest rate below the growth rate of the economy - could help restore the efficacy of monetary policy in controlling inflation.

More recently, the models of the 'fiscal theory of the price level' (as first discussed in Woodford, 1994) have suggested that fiscal policy, rather than monetary policy, can be the main determinant of inflation. In these models, the price level is the only variable that can balance the government's inter-temporal budget constraint. If the sequence of future budget surpluses is exogenously given, there is only one price level that can make the stock of nominal bonds inherited from the past consistent with the present value of those primary surpluses. Therefore, the government's inter-temporal budget constraint determines the price level. For illustration, one can consider a case where the government introduces a tax cut that reduces the sum of the present discounted value of future primary balances. As a result, real household wealth increases, boosting aggregate demand and the price level. The real value of

\footnotetext{
${ }^{7}$ The literature has also analyzed the interaction between fiscal and monetary policy along other dimensions: one prominent strand of the literature focuses on the issues related to the coordination of monetary and fiscal policy (for example, Alesina and Tabellini (1987); Debelle and Fischer (1994); Dixit and Lambertini (2001); Buti and others (2002)). Another strand examines jointly optimal monetary and fiscal policy (for example, Lucas and Stokey (1983); Chari and others (1991); Benigno and Woodford (2003); Beetsma and Jensen (2002); Schmitt-Grohe and Uribe (2000); Correia and others (2003)).

${ }^{8}$ Sargent and Wallace (1981) also show that when the demand for base money depends on expected inflation, tighter money today can lead to higher inflation not only eventually, but starting today.
} 
government debt thereby declines, helping restore balance in the inter-temporal budget constraint. ${ }^{9}$

A number of studies have empirically examined the extent of monetary and fiscal policy interaction in industrial countries. Most of these studies find that monetary policy typically has not accommodated fiscal policy, and some find that monetary policy has tended to tighten in response to loose fiscal policy. Melitz $(1997,2002)$, for example, estimates the joint reaction function of the monetary and fiscal authorities for nineteen OECD countries over the period 1960-95, and finds that monetary and fiscal policy have tended to move in opposite directions. Wyplosz (1999) obtains a similar result for the EMU countries following the 1992 Maastricht Treaty. ${ }^{10}$

There is however relatively little empirical evidence regarding emerging markets, where the above issues are perhaps even more pertinent. Tanner and Ramos (2002) evaluate whether the policy regime in Brazil during the 1990s can be characterized as either fiscal or monetary dominant. Results show some evidence of a monetary dominant regime for 1995-97, but not for the decade of the 1990s as a whole. In a cross-sectional framework, IMF (2003) estimates a separate fiscal policy reaction function for a group of industrial and emerging market economies and finds that the response of primary surpluses to public debt is stronger in the former set of countries than in the latter.

Zoli (2005) provides a more systematic analysis of the links between fiscal and monetary policy in emerging markets. She first conducts a test of fiscal dominance employing a VAR model to assess whether primary balances are set exogenously, and independently from public sector liabilities, in a sample of six emerging market countries (Argentina, Brazil, Colombia, Mexico, Poland and Thailand). Such an approach shows a regime of fiscal dominance in Argentina and Brazil during the 1990s and early 2000s, with mixed results for the other countries. In the analysis of whether fiscal variables enter significantly in the central bank's reaction function, results show that the conduct of monetary policy is not directly affected by changes in real primary balances. ${ }^{11}$

\section{B. Impact of Fiscal Policy on Sovereign Spreads, Interest Rates, and Exchange Rates}

The theoretical and empirical literature indicates that fiscal policy may affect a number of monetary variables, including interest rates, sovereign spreads, and exchange rates. Many of the empirical studies examine the impact of fiscal policy on individual monetary variables, rather than explore the interrelationships between them and fiscal policy. They suggest for

\footnotetext{
${ }^{9}$ Studies that focus on this strand of the literature include Auernheimer and Contreras (1990); Benhabib and others (2001); Canzoneri and Diba (1998); Canzoneri and others (2001, 2002); Christiano and Fitzgerald (2000); Cochrane (1998, 2001); Leeper (1991); Loyo (1999); Sims (1994, 1995, 1997, and 1998); and Woodford (2000). However, this view has been criticized on theoretical grounds, and has found mixed empirical support. See, for example, Buiter (1997); McCallum (1997); and Cushing (1999).

${ }^{10}$ Zoli (2005) provides an extensive account of empirical studies in similar vein.

${ }^{11}$ Countries included in the sample are Brazil, Chile, Colombia, Mexico, Poland, South Africa, and Thailand.
} 
instance that fiscal variables tend to be significant determinants of real interest rates and interest spreads in emerging markets. ${ }^{12} 13$ The empirical literature on the impact of fiscal policy on exchange rate movements has focused mainly on impact of fiscal policy on a country's vulnerability to currency crises. Evidence suggests that large government deficits or market perceptions of lack of fiscal sustainability make an economy more vulnerable to currency crises (See Kopits, 2000; and Hemming and others, 2003). ${ }^{14}$

More recent papers consider multi-equation models to investigate different channels of interaction and transmission from fiscal policy to the monetary variables (Blanchard, 2004; Favero and Giavazzi, 2004; and Giavazzi, 2003). Analyzing the case of an inflation-targeting regime in an emerging market that is vulnerable to capital flows reversal, a key result is that large public debt, by boosting credit default risk, pushes the economy into a bad equilibrium, where a restrictive monetary policy can have unconventional effects. In other words, the tightening of monetary policy can lead to a lowering of inflationary expectations, which can then reduce long-term rates, and eventually end-up being less restrictive, or even be stimulatory.

Empirical evidence regarding the channel of transmission of fiscal dominance has been provided by Blanchard (op. cit.); and Favero and Giavazzi (op. cit.). In addition, Zoli (2005) estimates the impact of news concerning fiscal variables and fiscal policy on daily movements in sovereign spreads and exchange rate in Brazil from 2002-04. Results show that fiscal events significantly influenced Brazil's sovereign spread and its exchange rate in that period. Emir, Özatay, and Şahinbeyoğlu $(2004,2005)$ also evaluate the impact of news, including that related to primary balance data, on secondary market government securities yields in Turkey (May 2001-December 2002), but find no significant impact on the threemonth treasury bill rate of unanticipated developments ("news") concerning the primary balance

\footnotetext{
${ }^{12}$ See, for example, Edwards (1984,1986); Cline (1995); Cantor and Packer (1996); Cline and Barnes (1997); Eichengreen and Mody (1998); Min (1998); Kamin and Kleist (1999); Arora and Cerisola (2001); Dell' Ariccia and others (2002); Ferrucci (2003); IMF(2004); Zoli (2004).

${ }^{13}$ See Easterly and others (1994); and Agenor and Montiel (1996). For industrial countries, empirical studies on the relationship between fiscal policy and interest rates have found mixed results. For example, Plosser (1982, 1987); Boothe and Reid (1989); and Evans (1985, 1987a,b) do not find any significant relationship between fiscal deficits and interest rates, whereas Wachtel and Young (1987); Ford and Laxton (1999); Kitchen (1996); Elmendorf (1996); and Canzoneri and others (2002) find that budget deficits have a significant impact on interest rates.

${ }^{14}$ For industrial countries the evidence on the impact of fiscal policy on exchange rate movements is mixed. Some studies find a positive and significant relationship between fiscal expansions and the exchange rate (Feldstein (1986); Melvin and others (1989); Beck (1993)), while others do not find any statistically significant relationship (McMillin and others (1990); Koray and Chan (1991)).
} 


\section{Cross-Country Analysis}

\section{A. Methodology}

This section evaluates whether the reaction of monetary policy to inflation is affected by the stock of government liabilities across a wide cross-section of emerging markets. The analysis is undertaken in two stages: first, we estimate the following regression country-by-country:

$$
\text { Stage 1: } \quad r_{i t}=\alpha_{i}+\beta_{i} \pi_{i, t-1}+\varepsilon_{i t}
$$

where $r_{i t}$ is the overnight interest rate for country $i$, and $\pi_{i, t-1}$ is the rate of inflation over the past twelve months (lagged by one period). This rule, used by Alesina and others (2001), can be viewed as a simplified version of the Taylor rule without the output gap. The omission of the latter variable essentially reflects the significant difficulties entailed in computing potential output, and hence the output gap for emerging market economies. (For alternative specifications see below). In the second stage, we run cross-section regressions to explain the cross-country variation in the sensitivity of the overnight rate to inflation estimated from equation (1).

$$
\text { Stage 2: } \quad \hat{\beta}_{i}=\alpha+\lambda Z_{i}+v_{i}
$$

where $\hat{\beta}_{i}$ is the estimated parameter for country $i$ from equation (1); the set of explanatory variables $Z_{i}$ includes total public debt (as share of GDP), external debt (as share of GDP), external debt as share of total debt, a measure of financial liberalization, and an index of central bank independence. These variables are averaged over the time period used to estimate the stage 1 regressions, and in general range over early 1990s to 2004. While our interest is in the impact of the debt variables on the interest elasticity of inflation, it is important to note that both financial liberalization and central bank independence are likely to exert some impact on this elasticity directly, and should be taken into account. The equation is estimated using weighted least squares (the standard errors of $\beta$ are used for the weighting), which takes into account the fact that the dependent variables are measured with different degrees of precision across countries as reflected in the precision of the coefficient estimates in equation (1).

Although equations (1) and (2) are the basic estimating equations for this cross country analysis, two alternative specifications are also estimated to test the robustness of the results. First, we estimate a variant of equation (1) that posits the overnight interest rate for country $i$ as a function of the lagged inflation rate, and the change in inflation over the preceding two periods:

$$
r_{i t}=\alpha_{i}+\beta_{i} \pi_{i, t-1}+\gamma_{i}\left(\pi_{i, t-1}-\pi_{i, t-2}\right)+\varepsilon_{i t}
$$

This specification can be viewed as a simple rule in an inflaion targeting regime that defines the nominal interest rate target as a function of the deviation of inflation from the inflation target. (The inflation rate in period $t-2$ is used to proxy for the target). 
We also estimate panel regressions of the following form:

$$
r_{i t}=\alpha_{i}+\beta_{1} \pi_{i, t-1}+\beta_{2}\left(\operatorname{debt}_{i, t}\right)+\beta_{3}\left(\operatorname{debt}_{i, t}\right) *\left(\pi_{i, t-1}\right)+\varepsilon_{i t}
$$

This can be seen as an additional robustness check, since in this panel format the impact of cross-country and intertemporal variation is explicitly brought to bear, and the two-stage regressions noted above are essentially subsumed into one.

\section{B. Data}

The analysis is conducted for a set of twenty-five emerging market economies, with a wide range of public debt profile, financial liberalization, and central bank independence. ${ }^{15} \mathrm{We}$ use quaterly data covering the period 1992 Q1 to 2005 Q2, although the sample size is smaller for some countries. With regard to the stage 1 regression, quarterly data on overnight interest rates are obtained from Bloomberg, Datastream and IFS. Inflation is measured as the annual percentage change in the Consumer Price Index, obtained from IFS. With regard to the explanatory variables in the stage 2 regression, data on debt-to-GDP, and external debt-toGDP are obtained from the an IMF internal public debt data set. The index of financial liberalization is an updated version of the Abiad and Mody (2003) index. ${ }^{16}$

Central bank independence is proxied by the 'Central Bank Governor's turnover rate index' developed by Dreher, Sturm, and de Haan (2005). This indicator is based on the proposition that, above some threshold, a higher turnover of central bank governors indicates a lower degree of independence. The choice of this particular indicator of central bank independence is driven largely by the fact that it is the only available index covering most of the emerging markets included in our analysis over the entire sample period. ${ }^{17}$

\footnotetext{
${ }^{15}$ The sample includes Argentina, Brazil, Bulgaria, Chile, China, Costa Rica, Cote d' Ivoire, Ecuador, Hungary, India, Indonesia, Korea, Lebanon, Malaysia, Mexico, Morocco, Nigeria, Pakistan, Peru, Philippines, Poland, South Africa, Turkey, Uruguay, and Venezuela.

${ }^{16}$ The criteria used for the construction of the index comprise financial policy changes along the following seven dimensions: (i) Credit controls and reserve requirements; (ii) Interest rate controls; (iii) Entry barriers; (iv) State ownership; (v) Policies on securities markets; (vi) Banking regulations; and (vii) Restrictions on the capital account. The index is a graded measure along a 4-point scale ranging from 0-3.

${ }^{17}$ Alternative indicators of central bank independence are legal indices based on regulations on the position of the central bank. However, such measures are often incomplete and noisy indicators of actual independence, as laws cannot unambiguously specify the division of power between central banks and political authorities under all circumstances. Moreover, even when laws are relatively explicit, actual practice may diverge from them. Cukierman (1992) argues that legal independence measures may be a better proxy for actual independence in industrial countries than in developing countries. Cukierman (1992) and Cukiermam; Webb and Neyapti (1992); develop a yardstick for central bank independence, which is not based on central bank laws but on the actual average term of office of the central bank governor.
} 


\section{Results}

Table 1 shows the results of the regressions that explain the cross-country variation in the response of the overnight interest rate to inflation estimated in equation (1). We find strong evidence that the response of interest rate to inflation weakens with debt-to-GDP and external debt-to-GDP: the higher the debt ratios, the lower the response (see first three columns of the Table 1). This result is generally robust across the various specifications noted below, and prima facie appears to be consistent with the proposition that higher levels of public indebtedness may end up constraining the response of the monetary authorities to changes in inflationary pressure.

It is also noticeable that the coefficient on the external debt ratio is larger, although when both overall debt and external debt are included separately, only the overall debt variable is significant. The results of adding the financial liberalization index as a control variable are shown in columns (4)-(6). The coefficient of the index is positive and statistically significant in column (6), implying that the higher is the degree of financial liberalization, the stronger is the response of the overnight interest rate to inflation. The index, however, is not statistically significant in the other specifications.

Columns (7)-(10) report the regressions results with the index of central bank independence as an additional control variable. We do not find any significant relationship between the response of interest rate to inflation and the degree of central bank independence. Taken together, these findings suggest that high levels of debt are likely to constrain the conduct of monetary policy in emerging market economies. 


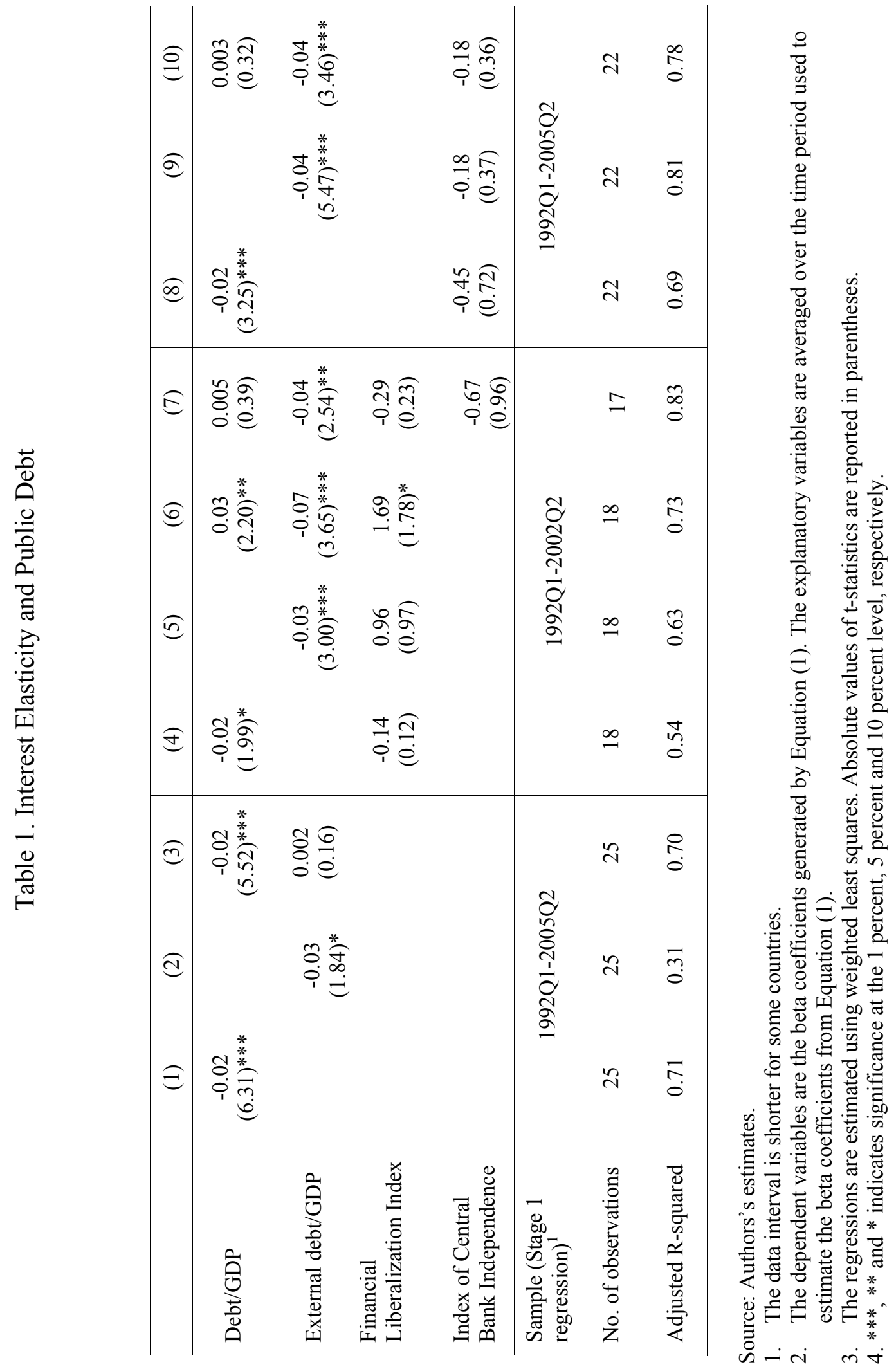




\section{NeWS ANALYSIS}

The above cross-country analysis illustrates the constraint that might be imposed on the monetary authority's reaction function in emerging markets with different levels of debt. There is of course further scope for investigation, since as noted earlier, fiscal policy can affect monetary policy also through the impact on credit risk, sovereign spreads, interest rates, and exchange rates. The second part of our analysis explores these other channels of transmission, by using daily data to estimate how markets react to news regarding fiscal policy and fiscal variables.

This analysis brings together two different strands of literature. First, it draws upon the notion that asset prices are affected by the arrival of new information. There is a rich literature on the role of information in financial markets, and one aspect of this literature focuses on the effects of macroeconomic data announcements on various markets including bonds and currencies. Macroeconomic data announcements have been used in the literature to test the market efficiency and rational expectations hypothesis.

More recently, macroeconomic announcements have been used to study the microstructure of financial markets and the role of private information in the formation of asset prices. However, most existing studies have focused on mature financial markets and studies focusing on the impact of macroeconomic announcements in emerging markets are limited. ${ }^{18}$

The second strand of literature that our analysis draws upon concerns the channels of transmission of fiscal dominance emphasized by Blanchard (previously cited), and Favero and Giavazzi (previously cited ). We estimate reduced form models, focusing on three segments of the transmission mechanism, namely the impact of fiscal policy on country premiums, interest rates and exchange rates. Specifically, we evaluate the effect of fiscal news on daily changes in country premium, exchange rates and interest rates, while controlling for other factors that affect such movements.

Following the methodological approach of Zoli (2005), we estimate the following reduced form equations for Brazil, Poland, and Turkey, three emerging market economies characterized by relatively high levels of public debt:

$$
Y_{t}=\alpha+\sum_{i=1} \beta_{i} X_{i t}+\varepsilon_{t}
$$

where $Y_{t}$ is either the daily percentage change in the country premium, or the daily percentage change in the nominal exchange rate vis-à-vis the US dollar, or the daily percentage change in domestic long-term interest rate. Country premium is measured by the country sub-indices of the Emerging Market Bond Index- Plus (EMBI Plus) computed by JP Morgan. ${ }^{19}$ The sample period is January 1, 2002-December 31, 2004.

\footnotetext{
${ }^{18}$ Recent studies focusing on emerging markets are Ganapolsky and Schmukler (1998); Kaminsky and Schmukler (1999); and Andritzky, Bannister, and Tamirisa (2005).

${ }^{19}$ The EMBI Plus tracks total returns for actively traded external debt instruments in emerging markets. It includes US-dollar denominated Brady bonds, Eurobonds, and traded loans issued by sovereign entities. The spread measures
} 
The set of regressors $X_{t}$ includes a group of variables measuring the unexpected component of announcements of major fiscal and macroeconomic variables, as well as the unexpected component of data releases on US macroeconomic variables, such as changes in the Fed Funds rate. By isolating the unexpected component of announcements we can test if markets react to surprises. We measure surprise as the difference between official data announcements and the forecasts available in the days preceding the announcements. Forecasts are obtained from Bloomberg and JP Morgan's Global Data Watch. We divide each macroeconomic surprise series by its standard error to make the regression coefficients easily interpretable as the effect of a onestandard-error surprise in that release.

The regressor and others contain dummy variables that capture particular events concerning fiscal policy that might be relevant for investors assessing the default probability. Such events are grouped into two categories. The first includes concrete fiscal policy actions that might have enhanced investor confidence, such as budgetary cuts, or substantive steps in the advancement of pension and tax reforms $(A C T I O N)$. The second comprises government announcements representing statements unaccompanied by immediate concrete actions, such as the declaration of the intention to raise the public sector surplus, also aiming at reassuring market participants (ANNOUNCEMENT). Given that the response to good and bad news may be asymmetric, we also break these two news items into "good" or "bad," and introduce them separately in the regressions (Action_good, Action_bad, Announcement_good, Announcement_bad.

The regressor and others include dummy variables for election days (Elections), IMF related news $(I M F)$, and four dummies corresponding to upgrades or downgrades of rating or outlook by the major rating agencies (Rating_up, Rating_down, Outlook_up, Outlook_down). For Turkey and Poland, we include also a dummy variable capturing news on the structural reform process towards the EU accession, and other EU related news $(E U)$. Finally, a dummy is entered specifically for January 28, 2004, the day when the Federal Reserve Bank indicated that an increase in the Fed Fund rate was on the way, which was followed by significant movements in the emerging economies' bond market (US_EXPFEDRATEUPUP). All explanatory variables are entered in the regressions also with a lag, to account for the possibility of delays in the response of spreads and exchange rates to news. ${ }^{20}$

\section{A. Results}

Before turning to the regressions estimating the impact of fiscal variables and fiscal policy events on country premium, exchange rate, and long-term interest rate, respectively, we analyze the relationship among these three dependent variables using impulse response functions. ${ }^{21}$ In the case of Brazil, the response of the EMBI spread to shocks to the exchange rate and to long-term

the difference between the yield on a dollar-denominated bond issued by a sovereign and the yield on a comparable bond issued by the U.S. Treasury.

${ }^{20}$ See Appendix II for a detailed description of the variables.

${ }^{21}$ We use the Generalized Impulse approach proposed by Pesaran and Shin (1998) to construct an orthogonal set of innovations that does not depend on the VAR ordering. 
interest rate is significant, but very short lived. Similarly both the exchange rates, and the interest rates respond significantly for few days only to shocks to the other two endogenous variables (Figure 1, Appendix 1). Also for Poland the impulse response funtions suggest that shocks to one of the endogenous variables have little impact on the other two (Figure 2, Appendix I).

In fact, shocks to the EMBI spread neither have a significant impact on the exchange rate nor on long-term interest rates. Similarly, shocks to the exchange rate have a very brief impact on interest rate, and no significant impact on country premium. Shocks to the interest rates have a short effect on the exchange rate, but no effect on the EMBI spread. The impulse response functions for Turkey indicate that the exchange rate responds positively and significantly to shocks to long-term interest rates, but such response is very short lived (Figure 3, Appendix I). Shocks to the EMBI spread have a significant, but very brief impact on long-term interest rates. Shocks to the exchange rate and to long-term interest rate have virtually no effect on the country premium.

All in all, these findings suggest that, in Brazil, Poland and Turkey, shocks to one of the three endogenous variables under consideration appear to have little impact on the other two. While this is of substantial interest in its own right, it also suggests that the reduced form approach adopted for the following empirical analysis seems appropriate.

\section{Brazil}

Column 1 of Table 2 shows the impact of news for a wide variety of variables on sovereign spreads for Brazil. With regard to the fiscal variables, data releases for primary public sector borrowing requirement (PRIMPSBR) do not appear to have a significant impact on spreads. Quite strikingly, news concerning fiscal policy actions, however, does have a marked impact on sovereign spreads. The coefficient of the variable $A C T I O N$ is negative and significant at the 5 percent level, suggesting that favorable news on fiscal policy actions reduced the perceived risk of default.

With regard to the monetary variables, the unanticipated component of changes in the central bank's policy rate (SELIC) does not have a significant impact on spreads, but changes in the Fed Funds rate (U.S. FED) do have a negative and significant impact. We also include a dummy variable capturing the expectation of an imminent increase in the Fed Funds rate, triggered by the Fed Monetary Committee's statements on 28 January 2004 (US_EXPFEDRATEUP). The coefficient of the lagged variable turns out to be positive and significant. This result is consistent with the findings in the literature on emerging market spreads, showing that movements in country premiums are mainly driven by global liquidity, and lenders' appetite for risk (Kamin and Kleist, 1999; Calvo and others, 1993; Calvo, 2002; and Kumar and Presaud 2003).

Among the other control variables, the IMF dummy (contemporaneous and lagged) has the expected negative and significant sign, indicating that a... Rating and outlook downgrades by rating agencies (Rating_down and Outlook_down) have the expected positive and highly significant coefficients. 
The estimates for the determinants of domestic long-term interest rate movements are reported in column 2 of Table 2. Changes in the domestic interest rate tend to move together with changes in the EMBI spreads, as indicated by the positive and significant coefficient. ${ }^{22}$ The main explanatory variables are monetary and ratings: the unanticipated change in the Selic rate (SELIC) is associated with increases in the domestic interest rate, while the outlook downgrades by rating agencies leads to an increase in interest rates. The dummy variable for election days (Elections) has a negative and significant coefficient, perhaps reflecting reduction in uncertainties associated with the run-up to the elections.

Column 3 reports the estimates of the impact of news on exchange rate movements. Since fluctuations in sovereign spreads are transmitted to the exchange rate via changes in capital flows, we added the lagged change in the EMBI spread as a regressor. The coefficient of this variable turns out to be positive and highly significant. The variable $A C T I O N$ has a negative and significant coefficient, implying that good news on fiscal policy actions led to an appreciation of the exchange rate.

In addition to this direct effect, news concerning fiscal policy actions also has an indirect effect on the exchange rate through its impact on the EMBI spreads. However, unexpected changes in the primary public sector borrowing requirement does not have a significant impact on exchange rate changes (the coefficient of the variable accounting for such events (PRIMPSBR) is insignificant), and is in line with the estimates for the spreads and the interest rate regressions. Unexpected changes in the Selic rate (SELIC) has a negative and significant impact on exchange rate changes. The dummies rating_down, outlook_up, and IMF also have significant coefficients, with the expected sign.

Taken together, the results in Table 2 provide mixed evidence of fiscal dominance in Brazil for the period of 2002-04. The news on fiscal policy actions is seen to affect changes in spreads and exchange rate in a significant manner. However, the unanticipated component of data releases on the budget balance appears not to have exerted an appreciable impact on these variables.

\footnotetext{
${ }^{22}$ This result is in line with our conjecture that domestic interest rates at all maturities are indirectly affected by fluctuations in the EMBI spread. Changes in the EMBI spread affect the exchange rate via capital flows. The policy rate (Selic) is affected because these exchange rate fluctuations in turn impact inflation expectations, and the central bank takes inflationary expectations into account when deciding on the level of the policy rate. Moreover, an increase in the EMBI spread can also affect inflation expectations directly if it generates concerns about the possibility of future monetization of public debt. Domestic interest rates at longer maturities are affected by the EMBI spread indirectly since fluctuations in the Selic rate move the term structure.
} 
Table 2. Impact of News on Spreads, Interest Rate, and Exchange Rate in Brazil, 2002-2004 1/

\begin{tabular}{|c|c|c|c|}
\hline Variable & $\Delta \mathrm{EMBI}$ & $\Delta$ Interest rate & $\Delta$ Exchange rate $2 /$ \\
\hline Lagged dependent variable & $0.21(4.66)$ & $\mathbf{- 0 . 1 4}(3.44)$ & \\
\hline Change in EMBI (-1) & & $0.12(4.64)$ & $(4.48)$ \\
\hline Change in exchange rate $(-1)$ & $\mathbf{- 0 . 3 0}(2.31)$ & & \\
\hline PRIMPSBR & $-0.30 \quad(0.59)$ & $-0.35 \quad(1.09)$ & $0.003 \quad(0.02)$ \\
\hline PRIMPSBR (-1) & $-0.24(0.41)$ & $-0.26(0.81)$ & $-0.12 \quad(1.01)$ \\
\hline SELIC & $-1.28(1.30)$ & $0.62(1.92)$ & $(6.16)$ \\
\hline SELIC(-1) & $0.62(0.70)$ & $1.73(2.98)$ & \\
\hline U.S. FED & $\mathbf{- 1 . 0 9}(1.81)$ & $\mathbf{- 0 . 8 2}(2.09)$ & \\
\hline US_EXPFEDRATEUP & & & $\mathbf{0 . 0 2}(15.49)$ \\
\hline US_EXPFEDRATEUP (-1) & $8.51 \quad(2.95)$ & & $\mathbf{- 1 . 0 1}(9.98)$ \\
\hline Announcement & $-0.63(0.75)$ & $-0.17 \quad(0.31)$ & \\
\hline Announcement (-1) & & & $-0.34 \quad(1.10)$ \\
\hline Action & $\mathbf{- 1 . 3 8}(2.28)$ & $-0.13(0.32)$ & $\mathbf{- 0 . 4 6} \quad(2.23)$ \\
\hline Rating_down & $5.81 \quad(3.99)$ & & $1.42 \quad(7.93)$ \\
\hline Outlook_up (-1) & & & $\mathbf{- 0 . 9 8} \quad(4.56)$ \\
\hline Outlook_down & & $4.93(4.50)$ & \\
\hline Outlook_down (-1) & $4.59(2.74)$ & $2.51 \quad(2.28)$ & \\
\hline Elections & & $-4.25(3.13)$ & \\
\hline IMF & $\mathbf{- 8 . 2 2}(2.80)$ & & $\mathbf{- 4 . 6 8}(113.19)$ \\
\hline $\operatorname{IMF}(-1)$ & $\mathbf{- 8 . 7 3}(2.98)$ & & $-4.50 \quad(17.98)$ \\
\hline Adjusted R-squared & 0.10 & 0.09 & 0.20 \\
\hline Number of observations & 685 & 689 & 717 \\
\hline
\end{tabular}

Source: Authors's estimates.

1/ All dependent variables are expressed as daily percentage changes.

2/ Estimated using Newey-West heteroskedasticity and autocorrelation consistent standard errors.

3/ All regressions are estimated including a constant (not reported). Absolute values of t-statistics are reported in parentheses. Coefficients in bold are significant either at the 1,5 , or 10 percent level. 


\section{Poland}

Column 1 of Table 3 presents the estimates of the impact of news on movements in country premium for Poland. The results show that news on fiscal policy had a significant effect on sovereign spreads during 2002-04. The coefficient of state budget balance is negative and significant, indicating that improved budget peformance led to lowering of spreads. Good fiscal policy actions (action_good) are seen to be associated with lowering of spreads. In contrast, surprises on the central bank's policy rate, however, do not have a significant impact on spreads.

Positive surprises on the U.S. Fed Funds rate lowered the change in spreads, a finding similar to that for Brazil. The coefficient of the dummy capturing the expectation of a rise in the Fed Funds rate, (US EXPFEDRATEUP), is positive and highly significant. These results are in line with those found for Brazilian spreads noted above, and also with the findings of Zoli (2005). The coefficients of U.S. CPI and U.S. Trade Balance are also positive and significant. Among the other control variables, only changes in credit ratings (Rating) has a significant impact on movements in spreads. An improvement in credit ratings is see to be associated with a significant lowering of spreads.

Next, consider the determinants of interest rate movements (Column 2, Table 3). Interest rate changes are affected by the unanticipated component of data releases on budget balance, inflation $(C P I)$ and GDP. News on the central bank's policy rate does not affect the movements of interest rate during this period. Furthermore, domestic interest rate tends to move together with changes in the U.S Fed Funds rate, as indicated by the positive and significant coefficient of the lagged U.S. FED variable. Contemporaneous and lagged surprises on U.S. CPI also have a positive and significant impact on long-term interest rate. The coefficient of US_EXPFEDRATEUP is highly significant, although the coefficients on the contemporaneous and lagged variable are of the opposite sign. Outlook upgrades by rating agencies (outlook_up) have a significantly negative influence on the interest rate. EU related news events are also associated with lowering of the interest rate.

Column 3 presents the estimates of the impact of news on exchange rate movements. The coefficient of the lagged change in EMBI spreads is significant but has the wrong sign. Exchange rate movements respond to news on budget balance and the central bank's policy rate. Within the set of U.S. macroeconomic news, change in the Fed Funds rate (U.S. FED) has a significant coefficient. However, the coefficients on the contemporaneous and lagged are with the opposite sign. The coefficient of U.S. Trade Balance is also positive and significant. As for the other control variables, good fiscal policy action (action_good), outlook upgrades (outlook_up), and outlook downgrades (outlook_down) are significant and correctly signed.

To sum, the above results indicate that fiscal news had a substantive impact on macro variables in Poland during 2002-04. Movements in the EMBI spread, interest rate, and the exchange rate were affected by both budget performance as well as news regarding fiscal policy actions. 
Table 3. Impact of News on Spreads, Interest Rate, and Exchange Rate in Poland, 2002-2004 1/

\begin{tabular}{|c|c|c|c|c|c|c|}
\hline Variable & \multicolumn{2}{|c|}{$\Delta \mathrm{EMBI} 2 /$} & \multicolumn{2}{|c|}{$\Delta$ Interest rate $2 /$} & \multicolumn{2}{|c|}{$\Delta$ Exchange rate $2 /$} \\
\hline Lagged dependent variable & -0.20 & $(2.90)$ & 0.10 & $(2.20)$ & -0.02 & $(0.63)$ \\
\hline Change in EMBI (-1) & & & & & -0.01 & $(3.11)$ \\
\hline CPI & & & 0.25 & $.69)$ & & \\
\hline CPI(-1) & 3.05 & $(2.01)$ & & & & \\
\hline GDP & & & $\mathbf{0 . 3 3}$ & $.95)$ & & \\
\hline State Budget Balance & -1.93 & $(3.11)$ & 0.36 & $(2.68)$ & 0.29 & $(3.46)$ \\
\hline Central Bank rate & -0.63 & $(0.61)$ & -0.03 & $(0.12)$ & -0.13 & $(2.01)$ \\
\hline Central Bank rate(-1) & -0.12 & $(0.19)$ & 0.01 & $(0.03)$ & -0.03 & $(0.31)$ \\
\hline U.S. FED & -0.38 & $(6.04)$ & & & -0.02 & $(2.32)$ \\
\hline U.S. FED(-1) & -1.08 & (13.64) & 0.27 & $(34.57)$ & 0.15 & $(26.91)$ \\
\hline U.S. CPI & & & 0.25 & $(2.07)$ & & \\
\hline U.S. CPI(-1) & 2.26 & $(2.31)$ & 0.26 & $(2.01)$ & & \\
\hline U.S. Trade Balance(-1) & 2.00 & $(3.30)$ & & & 0.21 & $(1.93)$ \\
\hline U.S. GDP (-1) & & & 0.34 & $(1.94)$ & & \\
\hline US_EXPFEDRATEUP & 8.74 & $(3.07)$ & -1.84 & $(14.29)$ & -0.43 & $(2.04)$ \\
\hline US_EXPFEDRATEUP(-1) & 14.53 & $(37.84)$ & 2.54 & $(37.10)$ & 0.94 & $(21.08)$ \\
\hline Announcement_good & & & -0.19 & $(0.51)$ & & \\
\hline Announcement_good(-1) & & & & & 0.26 & $(1.31)$ \\
\hline Action_good & & & -0.02 & $(0.04)$ & & \\
\hline Action_good (-1) & -6.84 & $(2.37)$ & & & -0.46 & $(2.30)$ \\
\hline Rating (-1) & -4.50 & $(2.69)$ & & & & \\
\hline Outlook up & & & & & 0.40 & $(8.19)$ \\
\hline Outlook_up (-1) & & & -1.66 & $(3.19)$ & -0.52 & $(1.84)$ \\
\hline Outlook_down (-1) & & & & & 0.75 & $(2.50)$ \\
\hline EU & & & -0.64 & $(2.07)$ & & \\
\hline Adjusted R-squared & & .04 & & .03 & & 03 \\
\hline Number of observations & & 85 & & 81 & & 73 \\
\hline
\end{tabular}

Source: Authors's estimates.

$1 /$ All dependent variables are expressed as daily percentage changes.

2/ Estimated using Newey-West heteroskedasticity and autocorrelation consistent standard errors.

3/ All regressions are estimated including a constant (not reported). Absolute values of t-statistics are reported in parentheses. Coefficients in bold are significant either at the 1,5, or 10 percent level. 


\section{Turkey}

The analysis for Turkey focused on the impact of news on macro variables for two sample periods: August 2001-December 2002, and August 2001-December 2004. ${ }^{23}$ Table 4 reports the estimation results for the former sample. With regard to the spreads regression (column 1), the coefficient of the variable capturing the surprise content of data releases on primary balance appears counterintuitive, and appears to imply that a higher than expected primary balance leads to lowering of spreads. This may reflect the paucity of reliable information and assessment given the inflationary environment. At the same time, the change in the central bank's policy rate (lagged by one period) has a positive and significant impact on spreads. ${ }^{24}$

Outlook downgrades by rating agencies (outlook_down) lead to an increase in spreads. However, the coefficients on the contemporaneous and lagged variable are of opposite signs. News concerning elections results in a lowering of spreads. We also added a dummy variable capturing news related to Turkey's potential EU accession. We split these news items into "good" or "bad" in terms of how it appeared to affect the likelihood of Turkey's accession recognizing the fact that the response to good and bad news may be asymmetric. ${ }^{25}$ Results show that "bad" EU news $\left(E U_{-} b a d\right)$ resulted in widening of the EMBI spread.

The impact of news on changes in the domestic interest rate is reported in column 2 . The coefficient of the lagged percentage change in the EMBI spread is positive and highly significant, implying that changes in domestic interest rate tend to move together with changes in spreads. Among the other macroeconomic news variables, only trade balance and changes in the central bank overnight rate (cbrate_chg) have a significant impact on interest rate changes. These results are in line with those reported by Emir, Ozatay, and Sahinbeyoglu (2004) who find the central bank policy rate change to be the only macroeconomic news variable that has a significant impact on the daily percentage change in the 3-month treasury bill rate. With regard to the other news dummies, Elections has a negative and significant impact on domestic longterm interest rate changes.

Column 3 reports the estimates of the impact of news on exchange rate movements. Exchange rate changes tend to oscillate in parallel with sovereign spreads, as indicated by the positive and significant coefficient of the lagged percentage change in EMBI spreads. Fiscal news, as captured by the unanticipated component of data releases on primary balance, does not have a significant impact on exchange rate changes. The coefficient of news on current account balance

\footnotetext{
23 The smaller sample was chosen to closely examine the relationship between the variables of interest during the heart of the financial crisis. Data limitations constrained efforts to carry out tests for the period before 2001 .

${ }^{24}$ Forecasts for the central bank's policy rate are not available and so the variable is expressed as the change in the policy rate from the previous day.

${ }^{25}$ EU related news are classified as good news whenever the Turkish parliament passed a reform towards the EU accession or set a date to convene for such measures. Bad news, on the other hand captures a dispute between the coalition parties regarding passing a necessary reform from the parliament, opposition from the opposition parties for such reforms, and negative developments at the end of 2002 for giving a "date" for Turkey.
} 
is significant, although its sign is counter-intuitive. With regard to U.S. macroeconomic news, lagged U.S. CPI and U.S. GDP have a positive and significant impact on exchange rate changes.

Table 4. Impact of News on Spreads, Interest Rate, and Exchange Rate in Turkey, 2001-2002

\begin{tabular}{|c|c|c|c|}
\hline Variable & $\Delta$ EMBI & $\Delta$ Interest rate & $\Delta$ Exchange rate \\
\hline Lagged dependent variable & $0.14(2.46)$ & $0.09 \quad(1.75)$ & $\mathbf{0 . 1 3}(2.26)$ \\
\hline Change in EMBI (-1) & & $0.21 \quad(4.70)$ & $\mathbf{0 . 1 8}(7.38)$ \\
\hline Change in EMBI (-2) & & & $\mathbf{0 . 0 8}(3.10)$ \\
\hline Current Account Balance & & & $\mathbf{0 . 5 4}(2.20)$ \\
\hline Trade balance & & $1.21 \quad(2.56)$ & \\
\hline Primary Balance & $\mathbf{- 1 . 2 5}(2.11)$ & $-0.35 \quad(0.77)$ & $0.11 \quad(0.46)$ \\
\hline Primary Balance (-1) & $-0.65(1.04)$ & $-0.38 \quad(0.79)$ & $0.002(0.01)$ \\
\hline U.S. CPI(-1) & & & $0.44 \quad(2.07)$ \\
\hline U.S. GDP (-1) & & $0.61 \quad(1.75)$ & (2.09) \\
\hline Cbrate_chg & $-0.13(0.44)$ & $\mathbf{0 . 4 1}(1.91)$ & $0.13 \quad(1.14)$ \\
\hline Cbrate_chg (-1) & $\mathbf{0 . 6 1}(2.17)$ & $\mathbf{- 0 . 5 0}(2.27)$ & $-0.05 \quad(0.44)$ \\
\hline Announcement (-1) & $0.60 \quad(0.55)$ & $0.91 \quad(1.09)$ & $-0.01 \quad(0.02)$ \\
\hline Action $(-1)$ & $-0.63 \quad(0.62)$ & $0.70 \quad(0.89)$ & -0.22 \\
\hline Outlook_down & $3.08(2.33)$ & & \\
\hline Outlook_down (-1) & $-4.05(3.59)$ & & \\
\hline Elections (-1) & $-6.34 \quad(2.94)$ & $\mathbf{- 1 0 . 0 6}(6.03)$ & \\
\hline EU_bad(-1) & $1.56(1.72)$ & & \\
\hline Adjusted R-squared & 0.11 & 0.24 & 0.26 \\
\hline Number of observations & 281 & 295 & 277 \\
\hline
\end{tabular}

Source: Authors's estimates.

1. All dependent variables are expressed as daily percentage changes.

2. All regressions are estimated including a constant (not reported). Absolute values of t-statistics are reported in parentheses. Coefficients in bold are significant either at the 1,5 , or 10 percent level. 
Table 5 reports the regressions for the sample running from August 2001 to December 2004. During this period, news on primary balance does not have a significant impact on changes in the EMBI spread. A higher than expected current account balance leads to lowering of spreads, while a positive surprise on U.S. CPI led to an increase in sovereign spreads. The coefficient of US_EXPFEDRATEUP (lagged) is positive and highly significant, implying that the expectation of an increase in the Fed Funds rate led to an increase in spreads. Zoli (2005) finds a similar result for Brazilian country premium.

Changes in domestic interest rate tend to move together with changes in EMBI spreads during this period (column 2). Also, positive surprises on the monthly CPI lead to an increase in the interest rate whereas news on primary balance had no impact on interest rates. Among the news on U.S. macroeconomic variables, U.S. FED, U.S. GDP, and U.S. PAYROLL have positive and significant impact on changes in the interest rate. Also, cbrate_chg and US_EXPFEDRATEUP have a significant impact on the interest rate, as in the shorter sub-sample. In addition, "bad" fiscal policy announcements and "bad" fiscal policy actions are highly significant and correctly signed, suggesting that investors over-react to bad political news. Kaminsky and Schmukler (1999) report a similar finding for nine Asian countries during the Asian crisis. Also, rating upgrades (rating_up) led to lowering of spreads during this period.

The estimates reported in column 3 show that changes in exchange rate move together with changes in EMBI spreads. U.S. FED, U.S. GDP, and U.S. PAYROLL also have positive and significant impact on changes in the exchange rate. The expectation of an increase in the Fed Funds rate (US_EXPFEDRATEUP) leads to a depreciation of the exchange rate during this period. Bad fiscal policy announcements and bad fiscal policy actions also result in depreciation of the exchange rate. We also test the effect of rating upgrades (downgrades) and outlook upgrades (downgrades) on changes in the exchange rate. Rating downgrades (rating_down) are associated with significant upward movement in the exchange rate. Outlook upgrades by rating agencies (outlook_up) led to significant appreciation of the exchange rate.

These results show that country premium was affected by budget performance and changes in the central bank's policy rate during Aug 2001- December 2002. Changes in the long-term interest rate responded to changes in the EMBI spread and the central bank's policy rate. Changes in the exchange rate moved together with changes in the EMBI spread. However, for the period August 2001-04, we do not find any significant relationship between data releases on primary balance and any of the dependent variables. Movements in the interest rate and exchange rate were affected by 'bad' fiscal policy announcements and 'bad' fiscal policy actions during this period.

We see the results in the preceding paragraph in light of Turkey's rapid transition from the financial crisis to a strong recovery characterized by robust economic growth and fiscal performance during the period in discussion. While the Turkish economy exhibited signs of fiscal dominance in 2001 and 2002, it clearly emerged out of it in 2003 and 2004 as strong policies were in effect. The fact that the data analysis of the larger sample does not yield a statistically significant relationship between the primary balance news and the monetary variables therefore likely reflects a cancelling out of the relationship seen in 2001/02 by subsequent data from a more "normal" period. 
Table 5. Impact of News on Spreads, Interest Rate, and Exchange Rate in Turkey, 2001-2004 1/

\begin{tabular}{|c|c|c|c|}
\hline Variable & $\Delta \mathrm{EMBI}$ & $\Delta$ Interest rate $2 /$ & $\Delta$ Exchange rate $2 /$ \\
\hline Lagged dependent variable & $\mathbf{0 . 0 7}(1.82)$ & $-0.05 \quad(0.88)$ & $0.14 \quad(3.54)$ \\
\hline Change in EMBI (-1) & & $0.25 \quad(3.89)$ & $\mathbf{0 . 1 6}(13.42)$ \\
\hline Current Account Balance & $-1.39(2.83)$ & & $\mathbf{0 . 3 7} \quad(2.63)$ \\
\hline CPIM (-1) & & $\mathbf{0 . 6 7}(2.31)$ & \\
\hline Primary Balance & $-0.64 \quad(1.23)$ & $0.09 \quad(0.31)$ & $-0.08 \quad(0.56)$ \\
\hline Primary Balance (-1) & $-0.22 \quad(0.42)$ & $-0.58 \quad(1.15)$ & $0.15 \quad(1.30)$ \\
\hline U.S. FED & & & $0.27(12.75)$ \\
\hline U.S. FED(-1) & & $\mathbf{0 . 5 6}(16.47)$ & \\
\hline U.S. CPI(-1) & $\mathbf{1 . 0 0 3}(2.19)$ & & \\
\hline U.S. GDP (-1) & & $0.45(1.93)$ & $\mathbf{0 . 2 2}(2.44)$ \\
\hline U.S. PAYROLL & & & $\mathbf{0 . 1 7}(2.15)$ \\
\hline U.S. PAYROLL(-1) & & $\mathbf{0 . 5 7}(2.02)$ & \\
\hline Cbrate_chg & $0.003(0.003)$ & $0.70 \quad(3.01)$ & $0.04 \quad(0.51)$ \\
\hline Cbrate_chg $(-1)$ & $0.78 \quad(0.78)$ & $-0.19 \quad(1.33)$ & $0.03 \quad(0.60)$ \\
\hline US_EXPFEDRATEUP & & & $-1.03(6.88)$ \\
\hline US_EXPFEDRATEUP (-1) & $15.09(5.44)$ & $1.48(15.80)$ & \\
\hline Announcement_bad & $0.40 \quad(0.15)$ & $\mathbf{0 . 6 1}(6.15)$ & $\mathbf{0 . 3 9}(10.34)$ \\
\hline Action_bad & $-0.70 \quad(0.26)$ & $0.56(4.01)$ & $\mathbf{0 . 0 8}(2.28)$ \\
\hline Rating_up & & $\mathbf{- 1 . 0 3}(2.75)$ & \\
\hline Rating_down (-1) & & & $\mathbf{0 . 3 7}(4.68)$ \\
\hline Outlook_up (-1) & & & $\mathbf{- 0 . 4 3}(3.36)$ \\
\hline Elections $(-1)$ & $-6.55(2.43)$ & $\mathbf{- 9 . 4 9}(36.67)$ & $\mathbf{- 0 . 2 3}(3.59)$ \\
\hline Adjusted R-squared & 0.07 & 0.16 & 0.28 \\
\hline Number of observations & 661 & 686 & 690 \\
\hline \multicolumn{4}{|c|}{$\begin{array}{l}\text { Source: Authors's estimates. } \\
\text { 1/ All dependent variables are expressed as daily percentage changes. } \\
\text { 2/ Estimated using Newey-West heteroskedasticity and autocorrelation consistent standard errors. } \\
\text { 3/ All regressions are estimated including a constant (not reported). Absolute values of t-statistics are reported in } \\
\text { parentheses. Coefficients in bold are significant either at the } 1,5 \text {, or } 10 \text { percent level. }\end{array}$} \\
\hline
\end{tabular}




\section{CONCLUding REMARKS}

This paper has aimed to explore the policy cost of high public debt. Given the variety of channels through which debt variables interact with other macroeconomic variables and policy actions, however, such an assessment requires a multifacted approach, such as the one adopted in the paper. The analysis of the interest rate-inflation relationship in emerging economies with different levels of debt suggests that monetary policy efficacy is weaker with higher levels of overall and external pubic debt. This, in turn, appears to illustrate a constraint that high public debt may impose on monetary policy.

The high-frequency data analysis of Brazil, Turkey, and Poland, with a focus on how essentially market-determined macro variables react to economic news, shows that when vulnerabilities are high, budget news has the most significant impact on spreads and the interest rate, and the impact of monetary policy is weakened. This effect is seen clearly for Turkey during 2001/02, but not when subsequent data are added to the regressions. One interpretation of the evident reduced fiscal dominance over time is that Turkey's vulnerabilities had been significantly reduced by 2003, and thus fiscal news was no longer having a disproportionate impact on the conduct of monetary policy.

The policy implication of our findings is clear. Since the fiscal environment can exert a significant impact on the efficacy of monetary policy directly and through expectations, high public sector debt could reduce the independence of monetary policy, as well as the efficacy of the transmission mechanism. Thus, in high-debt economies, the monetary-fiscal nexus needs to be taken into account in analyzing economic trends and vulnerabilities and in the design and implementation of policy. Conversely, reducing high public debt, while providing wellrecognized benefits in terms of reducing vulnerabilities and in providing flexibility to the budget, can, in addition, yield a substantial dividend in terms of enhancing the effectiveness of monetary policy instruments. 


\section{APPENDIXES}

\section{Impulse Response Functions}

Figure 1. Impulse Response Functions for Brazil

Response to Generalized One S.D. Innovations \pm 2 S.E.

Response of EMBIPLPERCH to EMBIPLPERCH

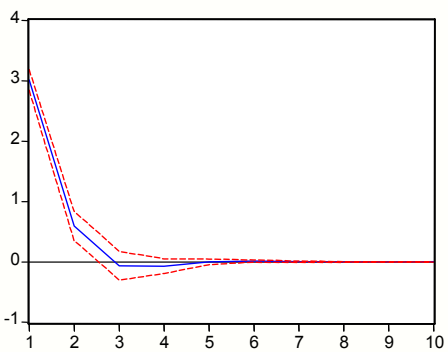

Response of ERUSDPERCHG to EMBIPLPERCH

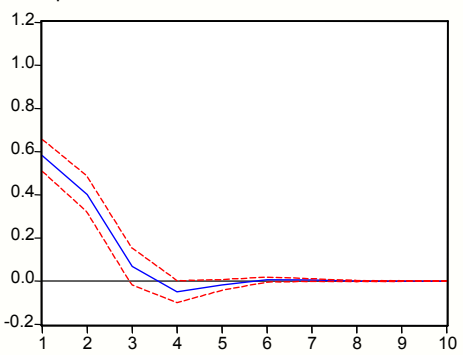

Response of INTTRATEPERCH to EMBIPLPERCH

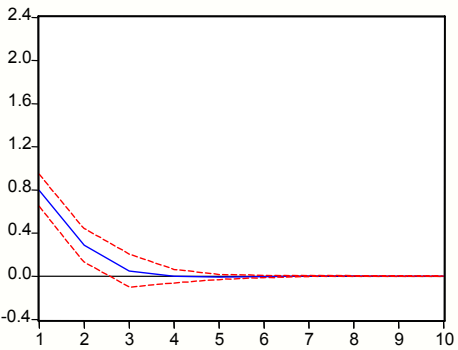

Response of EMBIPLPERCH to ERUSDPERCHG

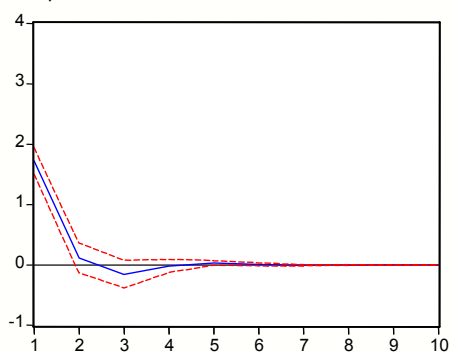

Response of ERUSDPERCHG to ERUSDPERCHG

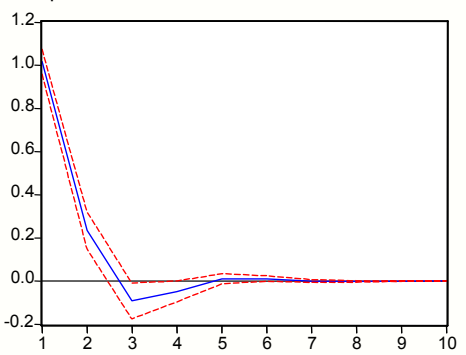

Response of INTTRATEPERCH to ERUSDPERCHG

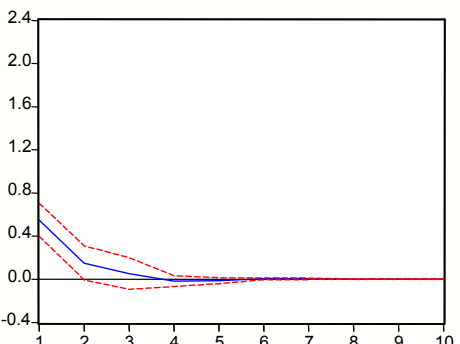

Response of EMBIPLPERCH to INTTRATEPERCH

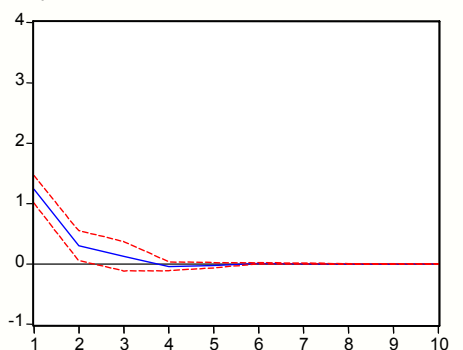

Response of ERUSDPERCHG to INTTRATEPERCH

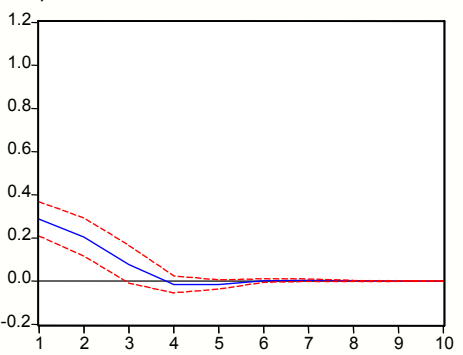

Response of INTTRATEPERCH to INTTRATEPERCH

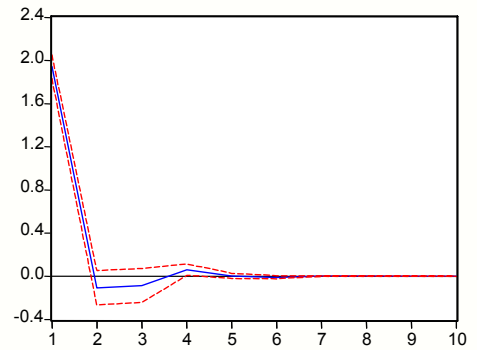

Source: Authors's estimates. 
Figure 2. Impulse Response Functions for Poland

Response to Generalized One S.D. Innovations \pm 2 S.E.
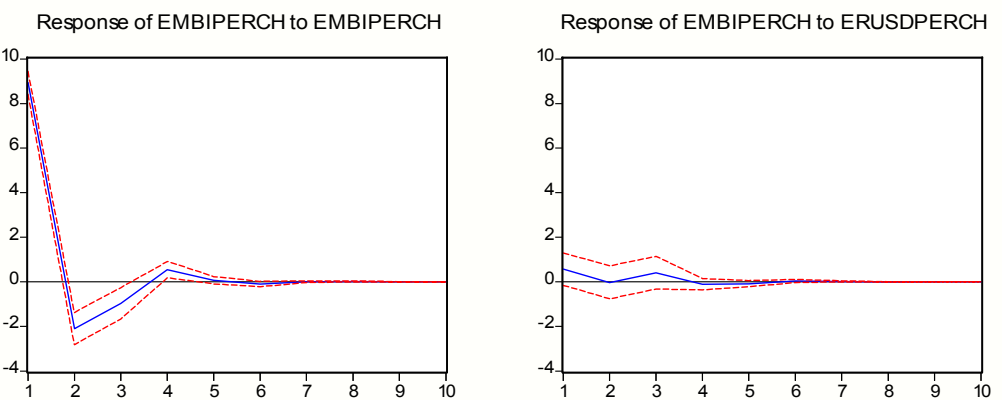

Response of EMBIPERCH to INTRATEPERCH

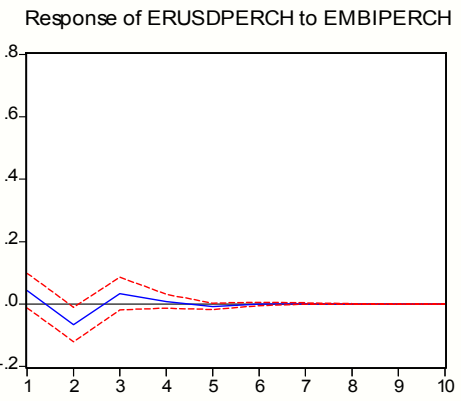

Response of ERUSDPERCH to ERUSDPERCH
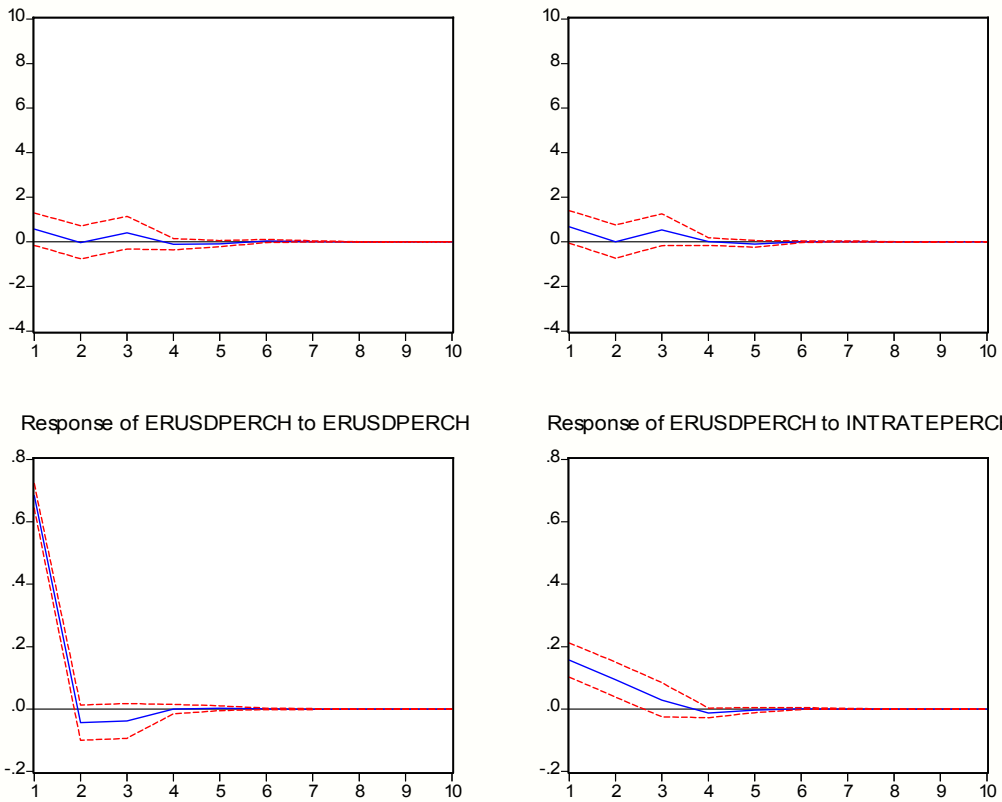

Response of ERUSDPERCH to INTRATEPERCH

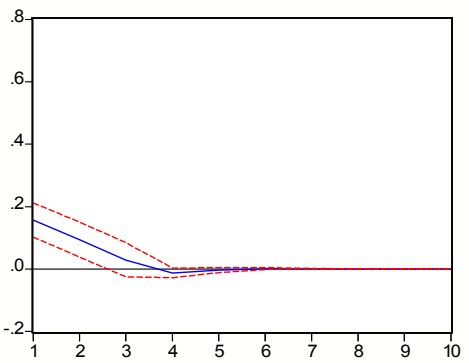

Response of INTRATEPERCH to EMBIPERCH

Response of INTRATEPERCH to ERUSDPERCH

Response of INTRATEPERCH to INTRATEPERCH
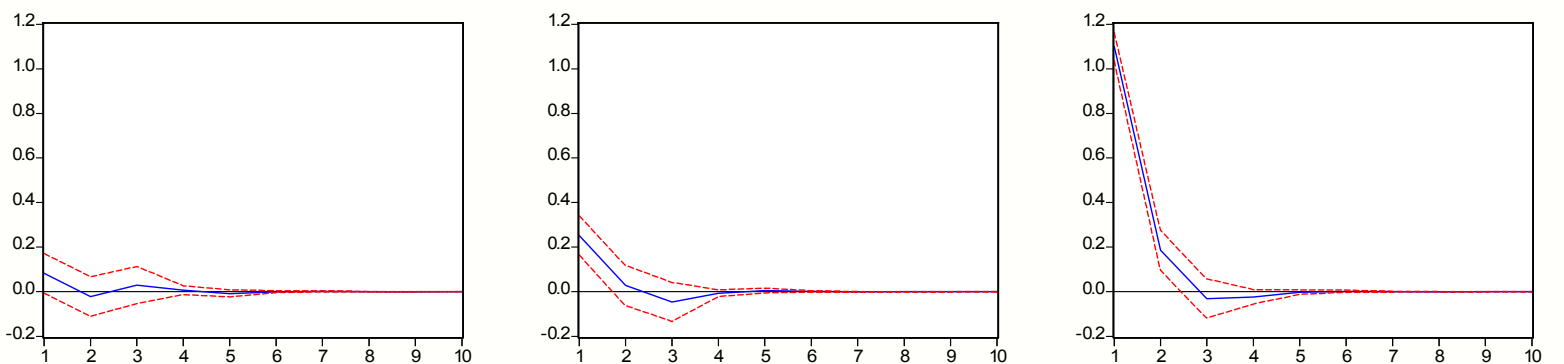

Source: Authors's estimates. 
Figure 3. Impulse Response Functions for Turkey, 2001-2004

Response to Generalized One S.D. Innovations \pm 2 S.E.

Response of EMBIPERCH to EMBIPERCH

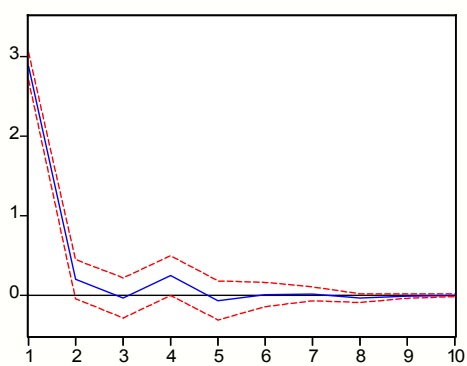

Response of ERATEPERCH to EMBIPERCH

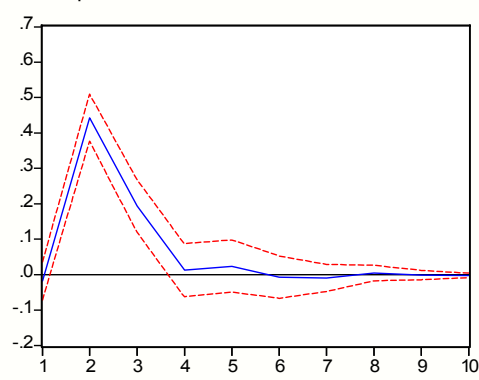

Response of INTPERCH to EMBIPERCH

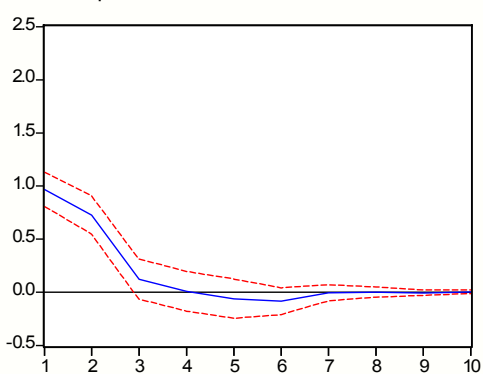

Response of EMBIPERCH to ERATEPERCH

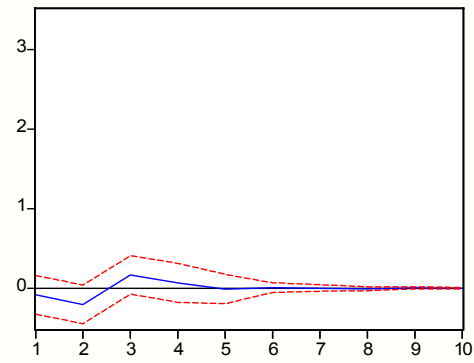

Response of ERATEPERCH to ERATEPERCH
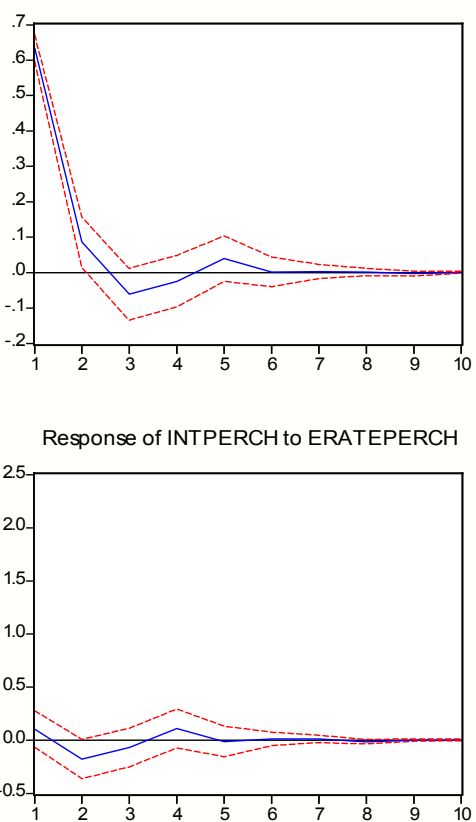

Response of EMBIPERCH to INTPERCH

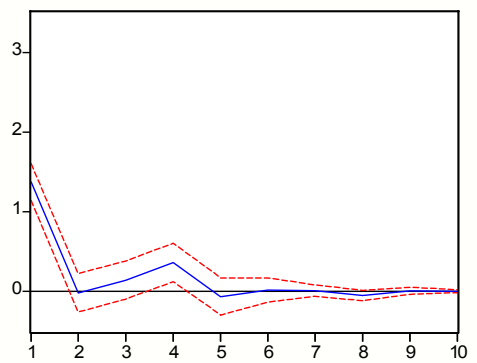

Response of ERATEPERCH to INTPERCH

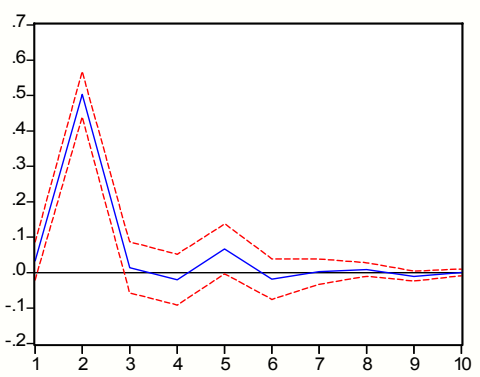

Response of INTPERCH to INTPERCH

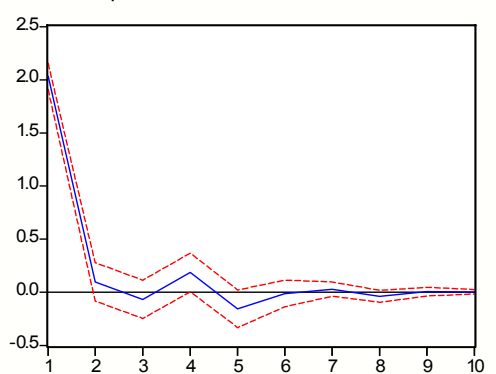

Source: Authors's estimates. 


\section{Variable Definitions and Data Sources for News Analysis}

\section{A. Brazil}

\section{Dependent variables:}

$\triangle$ EMBI: Daily percentage change in the Brazilian component of the Emerging Market Bond Index Plus (EMBI+). Source: Datastream and J. P Morgan.

$\Delta$ Interest rate: Daily percentage change in the domestic interest rate. The interest rate used is the '360 days future interest rate'. Source: IMF country data.

$\Delta$ Exchange rate: Daily percentage change in the exchange rate vis-à-vis the U.S. dollar. An increase indicates a depreciation. Source: Datastream.

\section{Explanatory variables:}

Primpsbr: Previous month Primary Public Sector Borrowing Requirement, difference between official data release and its forecasted value. Source: JP Morgan "Global Data Watch".

Selic: latest SELIC target rate (percent), difference between official data release and its forecasted value. Source: Bloomberg.

US_EXPFEDRATEUP: Dummy for expected increase in the U.S. Federal Funds rate (28 January, 2004).

Rating down: Dummy corresponding to the days when Brazil's rating was downgraded by one of the major rating agencies (Moody's, Standard \& Poor, Fitch IBCA).

Outlook up: Dummy corresponding to the days when Brazil's outlook was upgraded by one of the major rating agencies (Moody's, Standard \& Poor, Fitch IBCA).

Outlook down: Dummy corresponding to the days when Brazil's outlook was downgraded by one of the major rating agencies (Moody's, Standard \& Poor, Fitch IBCA).

Elections: A dummy for election days (October 7 and October 28, 2002)

IMF: dummy for the day when the IMF agreed to extend a US\$ 30 bn loan to Brazil (August 7, 2002)

\section{Announcements}

\section{-Good:}

4 September, 2002: Government raises target for primary surplus.

1 October, 2002: $\quad$ Front runner in the presidential election promises to honor public debt, if elected. 
17 October, 2002: $\quad$ Front runner in the presidential election promises to raise public sector surplus.

28 October, 2002: Newly elected president promises to honor public debt.

7 January, 2003: $\quad$ President maps strategy for pension reforms.

22 January, 2003: $\quad$ President guarantees commitment to tax reform.

5 February, 2003: $\quad$ Treasury sets limits and targets for debt stock and maturity.

14 February, 2003: President's speech in front of the Congress shows commitment to reforms.

22 February, 2003: President and governors sign a letter of intent calling for reforms of tax and pension system.

10 March, 2003: $\quad$ President promises to send to Congress proposal for tax and pension reform within the next month.

10 April, 2003: $\quad$ Government announces plan to keep 2004 budget surplus at 4.25 percent of GDP, which is the same as the IMF target for 2003.

22 September, 2004: Government announces plan to increase budget surplus from 4.25 percent of GDP to 4.5 percent.

\section{- Bad:}

16 December, 2004: Government announces it will pursue a primary budget surplus target of 4.25 percent, down form the previous primary budget goal of 4.5 percent.

\section{Actions}

\section{-Good:}

8 February, 2002: $\quad$ Government withholds 12.4 bln in spending from 2002 budget approved by Congress.

13 June, 2002: $\quad$ Government introduces package of measures to increase surplus, and pay back some of foreign debt.

30 October, 2002: New president rejects calls from state governors for an immediate renegotiation of debt.

18 December, 2002: $\quad$ Congress approved budget law envisages a surplus for 2003.

11 February, 2003: Government introduces a series of budgetary cuts.

30 April, 2003:

28 May, 2003:

4 June, 2003:

President delivers tax and pension reform plan to Congress.

23 July, 2003:

Lower house judicial committee approves tax reform bill.

Lower house judicial committee approves pension reform bill.

5 August, 2003:

Lower house pension ad hoc committee approves pension reform plan.

26 August, 2003:

Lower house approves pension reform (first vote).

27 August, 2003:

Lower house approves pension reforms (second vote).

3 September, 2003:

Lower house pension ad hoc committee approves tax reform plan.

23 September, 2003:

Lower house approves tax reform (first vote).

24 September, 2003:

3 October, 2003:

Government introduces spending cuts.

Lower house approves tax reforms (second vote).

Senate judicial committee approves pension reform.

5 November, 2003: $\quad$ Senate judicial committee approves tax reform.

26 November, 2003: Senate approves pension reforms (first vote).

11 December, 2003: Senate approves pension reforms (second vote) and tax reform (first vote). 
17 December, 2003: Senate approves tax reforms (second vote).

24 December, 2003: Congress approved budget for 2004 envisages a surplus at 4.25 percent of GDP, which is the same as IMF target from 2003.

5 February, 2004: Constitution and Justice committee approves second and third phase of tax and pension reforms.

29 April, 2004: Government raises minimum wage, which affects state pension payments, by a limited amount, ignoring pressures for a bigger rise.

4 May, 2004: $\quad$ Lower house approves legislation to enact the pension reform.

18 August, 2004: The supreme court rules that the public pension sector reform proposed by the government is constitutional.

- Bad

17 June, 2004: $\quad$ Senate raises minimum wages more than Lula's proposal.

\section{B. Poland}

\section{Dependent variables:}

$\triangle$ EMBI: Daily percentage change in the Polish component of the Emerging Market Bond Index Plus (EMBI+). The EMBI+ tracks total returns for actively traded external debt instruments in emerging markets. It includes US-dollar denominated Brady bonds, Eurobonds, and traded loans issued by sovereign entities. Source: Datastream and J. P Morgan.

$\Delta$ Interest rate: Daily percentage change in the domestic interest rate. The interest rate used is the yield on a local currency denominated government bond with 5-year maturity. Source: IMF country data.

$\Delta$ Exchange rate: Daily percentage change in the exchange rate vis-à-vis the U.S. dollar. An increase indicates a depreciation. Source: National Bank of Poland.

\section{Explanatory variables:}

CPI: Difference between official data release and the forecasted value of the previous month's Consumer Price Index (month on month). Source: Bloomberg

GDP: Difference between official data release and forecasted value of annual gross domestic product growth (in percent). Source: Bloomberg.

State budget balance: Difference between official data release and the forecasted value of the previous month's budget balance (in Polish Zloty, billions). Source: JP Morgan 'Global Data Watch'.

Central Bank rate: Difference between official data release and the forecasted value of the latest National Bank of Poland policy rate (14-day intervention rate). Source: Forecasts obtained from BRE Bank SA. 
Current account balance: Difference between official data release and the forecasted value of the previous month's current account balance. Source: Bloomberg

Announcement: Government announcements representing statements unaccompanied by immediate concrete actions, such as the declaration of the intention to raise the public sector surplus, also aiming at reassuring market participants (for a detailed list, see below).

- Good:

21 June, 2002:

Government agrees on a conservative ceiling for budget deficit.

16 July, 2002:

New ministry on finance pledges to trim budget deficit.

26 July, 2002:

In a speech to the parliament, ministry on finance pledges to trim budget deficit.

5 September, 2002: $\quad$ Ministry of finance pledges to narrow 2003 budget deficit.

19 September, 2002: Ministry of finance announces that government will lower target for budget deficit.

24 October, 2002: $\quad$ Ministry of finance announces that in January he will present a plan to reform public finances.

28 February, 2003: $\quad$ Ministry of finance outlines a new plan to reform public finance.

10 June, 2003: $\quad$ Cabinet sets lower 2004 budget target than expected.

10 July, 2003: $\quad$ Economy minister pledges to reduce the following year's budget.

5 November, 2003: $\quad$ Ministry of finance announces plan to introduce key reforms to trim budget deficit.

27 February, 2004: Government unveils a new austerity program.

8 June, 2004:

Government announces it will reduce the deficit in 2005 .

20 August, 2004: $\quad$ Ministry of finance pledges to reduce budget deficit in 2005.

- Bad

2 July, 2002:

Government revises upwards ceiling for budget deficit.

21 January, 2003: Ministry of finance announces that budget reforms proposal will be postponed.

25 July, 2003: $\quad$ Government revises upwards target for 2004 budget deficit.

10 September, 2003: Prime minister announces that fiscal policy tightening will start only in 2005.

24 September, 2003: Government announces it will order spending cuts starting only in the following years.

Action: Fiscal policy actions that might have enhanced investor confidence, such as budgetary cuts, or important steps in the advancement of pension and tax reforms (for a detailed list, see below).

- Good:

16 February, 2002: $\quad$ Parliament approves fiscal austerity plan.

8 October, 2003: $\quad$ Government approves some spending cuts.

27 January, 2004: Government approves program to reduce budget deficit.

30 August, 2004: Government sends a draft budget plan for 2005 envisaging a cut in headline deficit.

4 November, 2004: $\quad$ Senate approves increase in top income tax rate.

29 November, 2004: Parliament approves 2005 budget bill envisaging a lower deficit. 
- Bad:

17 June, 2003: $\quad$ Cabinet approves plan to reduce corporate income tax rate.

4 December, 2003: $\quad$ Parliament gives first approval to 2004 budget bill trimming deficit by a small amount.

19 December, 2003: Parliament approves 2004 budget envisaging higher deficit than in previous year.

16 July, 2004: $\quad$ Parliament approves a watered version of the government proposal to reform the pension system.

1 December, 2004: $\quad$ President fails to sign bill on increase in top income tax.

Rating: This variable takes the values $-1,0,1$, with -1 indicating a rating downgrade, 0 indicating no change, and +1 indicating a rating upgrade by any one of the major rating agencies (Moody's, Standard \& Poor's, and Fitch).

Outlook up: Dummy corresponding to the days when Poland's outlook was upgraded by one of the major rating agencies (Moody's, Standard \& Poor's, and Fitch).

Outlook down: Dummy corresponding to the days when Poland's outlook was downgraded by one of the major rating agencies (Moody's, Standard \& Poor's, and Fitch).

EU: EU accession related news that might have impacted investor confidence. The complete list is available upon request.

\section{Turkey}

\section{Dependent variables:}

$\triangle$ EMBI: Daily percentage change in the Turkish component of the Emerging Market Bond Index Plus (EMBI+). Source: Datastream and J. P Morgan.

$\Delta$ Interest rate: Daily percentage change in the domestic interest rate. The interest rate used is the 'benchmark bond interest rate' (in percent, compounded) which is derived from various local currency papers of different maturities. Source: IMF country data.

$\Delta$ Exchange rate: Daily percentage change in the exchange rate vis-à-vis the U.S. dollar. An increase indicates a depreciation. Source: Central Bank of Turkey.

\section{Explanatory variables:}

Current account balance: Difference between official data release and the forecasted value of the previous month's current account balance (in US\$ billion). Source: JP Morgan 'Global Data Watch'. Release dates were obtained from the Central Bank of Turkey. 
Trade balance: Difference between official data release and the forecasted value of the previous month's trade balance (in US \$ billion). Source: JP Morgan 'Global Data Watch'. Release dates were obtained from the Central Bank of Turkey.

CPI: Difference between official data release and the forecasted value of the previous month's Consumer Price Index (percent, month on month). Source: Bloomberg

Primary balance: Difference between official data release and the forecasted value of the previous month's primary balance (in TL trillions, current prices). Source: JP Morgan 'Global Data Watch'. Data release dates obtained from the Central Bank of Turkey.

Cbrate_chg: Daily change in the Central Bank's policy rate (overnight borrowing rate). Source: Bloomberg

US_EXPFEDRATEUP: Dummy for expected increase in the U.S. Federal Funds rate (28 January, 2004).

Rating up: Dummy corresponding to the days when Turkey's rating was upgraded by one of the major rating agencies (Moody's, Standard \& Poor's, and Fitch).

Rating down: Dummy corresponding to the days when Turkey's rating was downgraded by one of the major rating agencies (Moody's, Standard \& Poor's, and Fitch).

Rating: This variable takes the values $-1,0,1$, with -1 indicating a rating downgrade, 0 indicating no change, and +1 indicating a rating upgrade by any one of the major rating agencies (Moody's, Standard \& Poor's, and Fitch).

Outlook up: Dummy corresponding to the days when Turkey's outlook was upgraded by one of the major rating agencies (Moody's, Standard \& Poor's, and Fitch).

Outlook down: Dummy corresponding to the days when Turkey's outlook was downgraded by one of the major rating agencies (Moody's, Standard \& Poor's, and Fitch).

Outlook: This variable takes the values $-1,0,1$, with -1 indicating an outlook downgrade, 0 indicating no change, and +1 indicating an outlook upgrade by any one of the major rating agencies (Moody's, Standard \& Poor's, and Fitch).

Elections: A dummy for election days (November 3, 2002)

EU_bad, EU_good: EU accession related news that might have had a negative (EU_bad) or a positive (EU_good) impact on investor confidence. The complete list is available upon the authors.

IMF: IMF related news that might have enhanced investor confidence. The complete list is available upon the authors. 
Announcement:

- Good:

18 October, 2001: $\quad$ Minister of finance says he is determined to introduce large cuts in 2002 budget.

24 September, 2002: Minister of finance says the government will present soon to parliament a tax reform agreed with the IMF.

16 November, 2002: New government promises a series of economic reforms to keep IMF rescue package on track.

18 December, 2002: Government reaffirms commitment to primary budget target agreed upon with the IMF.

13 January, 2003: Government pledges to press forward with privatization.

- Bad:

8 October, 2002: $\quad$ Minister of finance says a tax reform package will be sent to parliament later than initially planned.

\section{Action:}

- Good:

12 December, 2001: Parliament approved 2002 budget with strict IMF backed spending cuts.

17 May, 2002: $\quad$ Government sends to parliament an IMF backed tax reform bill.

6 June, 2002: $\quad$ Parliament approves an IMF backed tax reform bill.

23 September, 2002: Government adopts a budget draft for envisaging a lower deficit.

18 October, 2002: $\quad$ Released draft budget bill for 2003 targets primary surplus in line with IMF target.

8 January, 2003: $\quad$ Government unveils revenue package.

3 March, 2003: $\quad$ Government drafts 2003 budget in line with IMF target.

25 March, 2003: $\quad$ Parliament passes the IMF backed 2003 budget.

9 May, 2003: $\quad$ Government approves a privatization plan.

17 July, 2003: $\quad$ Parliament passes social security reform bill.

11 February, 2004: Government sets new privatization plan for 2004.

-Bad:

29 January, 2003: $\quad$ President vetoes a tax reform bill.

News on U.S. macroeconomic variables:

U.S. Fed: Difference between official data release and the forecasted value of the latest Fed Funds target rate (in percent). Source: Bloomberg.

U.S. CPI: Difference between official data release and the forecasted value of the previous month's consumer price index inflation (in percent). Source: Bloomberg.

U.S. Trade balance: Difference between official data release and the forecasted value of the previous month's trade balance. Source: Bloomberg. 
U.S. GDP: Difference between official data release and the forecasted value of the latest annual gross domestic product (in percent). Source: Bloomberg.

U.S. Payroll: Difference between official data release and the forecasted value of the previous month's change in nonfarm payrolls (in thousands). Source: Bloomberg. 


\section{References}

Abiad, Abdul, and Taimur Baig, 2005, "Underlying Factors Driving Fiscal Effort in Emerging Market Economies,” IMF Working Paper 05/106 (Washington: International Monetary Fund).

Abiad, Abdul, and Ashoka Mody, 2003, "Financial Reform: What Shakes It? What Shapes It?" IMF Working Paper 03/70 (Washington: International Monetary Fund).

Agénor, P-R, and P.J. Montiel, 1996, Development Macroeconomics (Princeton, New Jersey: Princeton University Press).

Aktas, Zelal, Neslihan Kaya, and Ümit Özlale, 2005, “The Price Puzzle in Emerging Markets: Evidence from the Turkish Economy Using 'Model Based' Risk Premium Derived from Domestic Fundamentals," Central Bank of the Republic of Turkey, Research Department Working Paper No. 05/02 (Ankara).

Alesina, Alberto, and Guido Tabellini, 1987, "Rules and Discretion with Non-coordinated Monetary and Fiscal Policy," Economic Inquiry, Vol. 25 (October), pp. 619-30.

Alesina, Alberto, Olivier Blanchard, Jordi Galí, Francesco Giavazzi, and Harald Uhlig, 2001, "Defining a Macroeconomic Framework for the Euro Area: Monitoring the European Central Bank (3) (London: Center for Economic Policy Research).

Andritzky, Jochen R., Geoffrey J. Bannister, and Natalia T. Tamirisa, 2005, "The Impact of Macroeconomic Announcements on Emerging Market Bonds," IMF Working Paper 05/83 (Washington: International Monetary Fund).

Arora, Vivek, and Martin Cerisola, 2001, "How Does U.S. Monetary Policy Influence Sovereign Spreads in Emerging Markets?” Staff Papers, Vol. 48, No. 3, pp. 474-98 (Washington: International Monetary Fund).

Auernheimer, Leonardo, and Benjamin Contreras, 1990, "Control of the Interest Rate with a Government Budget Constraint: Determinacy of the Price Level, and Other Results" (Unpublished; Texas: A\&M University).

Beck, Stacie E., 1993, "Ricardian Equivalence Proposition: Evidence from Foreign Exchange Markets,” Journal of International Money and Finance, Vol. 12 (May) pp. 154-69.

Beetsma, Roel, and Herik Jensen, 2002, "Monetary and Fiscal Policy Interactions in a Microfounded Model of a Monetary Union,” CEPR Discussion Paper No. 3591 (London: Center for Economic Policy Research).

Benhabib Jess, Stephanie Schmitt-Grohe, and Martin Uribe, 2001, "Monetary Policy and Multiple Equilibria," American Economic Review, Vol. 91, (March) pp. 167-86. 
Benigno, Paolo, and Michael Woodford, 2003, "Optimal Monetary and Fiscal Policy: A LinearQuadratic Approach,” NBER Working Paper No. 9905 (Cambridge, Massachusetts: National Bureau of Economic Research).

Blanchard, Olivier, 2004, "Fiscal Dominance and Inflation Targeting: Lessons from Brazil," NBER Working Paper No. 10389 (Cambridge, Massachusetts: National Bureau of Economic Research).

Boothe, Paul M., and Bradford G. Reid, 1989, "Asset Returns and Government Budgets in a Small Open Economy," Journal of Monetary Economics, 23 (1) pp. 65-77.

Buiter, Willem H., 1997, "Neutrality, Price Level Indeterminacy, Interest Rate Pegs, and Fiscal Theories of the Price Level," Mimeo.

Buti, Marco, Werner Roeger, and Jan In't Veld, 2002, “Monetary and Fiscal Policy Interactions under a Stability Pact" in Marco Buti, Jurgen von Hagen and Carlos Martinez-Mongay (eds.) The Behavior of Fiscal Authorities, Palgrave.

Cantor, Richard, and Frank Packer, 1996, "Determinants and Impact of Sovereign Credit Ratings," Economic Policy Review, Federal Reserve Bank of New York, October, pp. 37-53.

Canzoneri, Matthew, and Behzad Diba, 1998, "Fiscal Constraints on Central Bank Independence and Price Stability," in J. Malo de Molina, J. Vinals, F. Gutierrez (eds.) Monetary Policy and Inflation in Spain, MacMillan.

Canzoneri, Mattew, Robert Cumby, and Behzad Diba, 2001, "Is the Price Level Determined by the Needs of Fiscal Solvency?" American Economic Review, Vol. 91, No. 5, pp. 1221-38.

2002, "Should the European Central Bank and the Federal Reserve be concerned about Fiscal Policy?" Mimeo.

Chari, V.V., L. J. Christiano, and P.J. Kehoe, 1991, “Optimal Fiscal and Monetary Policy: Some Recent Results," Journal of Money, Credit and Banking, Vol. 23, No. 3, pp. 519-39.

Christiano, Lawrence, and Terry Fitzgerald, 2000, "Understanding the Fiscal Theory of the Price Level,” NBER Working Paper No. 7668 (Cambridge, Massachusetts: National Bureau of Economic Research).

Cline, William R., 1995, International Debt Reexamined, (Washington: Institute of International Finance).

and Kevin J.S. Barnes, 1997, "Spread and Risk in Emerging Markets Lending," IIF Research Papers No. 97-1 (Washington: Institute of International Finance). 
Cochrane, John, 1998, “A Frictionless View of US Inflation,” in B. Bernake, and J. Rotemberg (eds.), NBER Macroeconomics Annual, pp. 323-84.

- 2001, "Long-Term Debt and Optimal Policy in the Fiscal Theory of the Price Level," Econometrica, Vol. 69, pp. 69-116.

Correia, Isabel, Juan Pablo Nicolini, and Pedro Teles, 2003, "Optimal Fiscal and Monetary Policy," Banco de Portugal Working Paper 3-03.

Cukierman, A., 1992, Central Bank Strategy, Credibility and Independence: Theory and Evidence (Cambridge, Massachusetts: MIT Press).

, S. Webb, and B. Neyapti, 1992, "Measuring the Independence of Central Banks and its Effect on Policy Outcomes," The World Bank Economic Review, Vol. 6 (September), pp. 352-98.

Cushing, Matthew, 1999, "The Indeterminacy of Prices under Interest Rate Pegging: The NonRicardian Case," Journal of Monetary Economics, Vol. 44, No. 1, pp. 131-48.

Debelle, Guy, and Stanley Fischer, 1994, "How Independent should a Central Bank be?" in Goals, Guidelines, and Constraints Facing Monetary Policymakers, Federal Reserve Bank of Boston, Conference Series No. 38.

Dell' Ariccia, Giovanni, Isabel Schnebel, and Jeromin Zettelmeyer, 2002, "Moral Hazard and International Crisis Lending: A Test,” IMF Working Paper 02/181 (Washington: International Monetary Fund).

Dixit, Avinash, and Luisa Lambertini, 2001, "Monetary-Fiscal Policy Interactions and Commitment versus Discretion in a Monetary Union," European Economic Review, 45, pp. 977-87.

Dreher, Axel, Jan-Egbert Sturm, and Jakob de Haan, 2006, "When is a Central Bank Governor Fired? Evidence Based on a New Data Set," Unpublished manuscript (February).

Easterly, William, Carlos A. Rodriguez, and K. Schmidt-Hebel, 1994, Public Sector Deficits and Macroeconomic Performance, (New York: Oxford University Press).

Edwards, Sebastian, 1984, "LDC Foreign Borrowing and Default Risk: An Empirical Investigation, 1976-80," American Economic Review, Vol. 74, No. 4, September, pp. 726-34.

- 1986, "The Pricing of Bonds and Bank Loans in International Markets," European Economic Review, 30, pp. 565-89. 
Eichengreen, Barry, and Ashoka Mody, 1998, "What Explains Changing Spreads on EmergingMarket Debt: Fundamentals or Market Sentiment?” NBER Working Paper No. 6408 (Cambridge, Massachusetts: National Bureau of Economic Research).

Elmendorf, D., "The Effects of Deficit-Reduction Laws on Real Interest Rates," Federal Reserve Board, Finance and Economics Discussion Series No. 1996-44.

Emir, Olcay Y., Fatih Özatay, and Gülbin Şahinbeyoğlu, 2004, "High Public Debt and Effects of News on Interest Rates," Central Bank of the Republic of Turkey Research Department, Working Paper No. 04/03.

— 2005, "Effects of US Interest Rates and News on the Daily Interest Rates of a Higly Indebted Emerging Country: Evidence from Turkey," Central Bank of the Republic of Turkey Research Department Working Paper No. 05/08.

Evans, Paul, 1985, “Do Large Deficits Produce High Interest Rates?” American Economic Review, 75 (1), pp. 68-87.

- 1987a, "Interest Rates and Expected Future Budget Deficits in the United States," Journal of Political Economy, Vol. 95, No. 1, pp. 34-58.

— 1987b, "Do Budget Deficits raise Nominal Interest Rates? Evidence from Six Countries," Journal of Monetary Economies, Vol. 20, No. 2, pp. 281-300.

Favero, Carlo A., and Francesco Giavazzi, 2004, "Inflation Targeting and Debt: Lessons from Brazil,” NBER Working Paper No. 10390 (Cambridge, Massachusetts: National Bureau of Economic Research).

Feldstein, Martin S., 1986, “The Budget Deficit and the Dollar”, in S. Fischer (ed.) NBER Macroeconomics (Cambridge, Massachusetts: National Bureau of Economic Research.

Ferrucci, Gianluigi, 2003, “Empirical Determinants of Emerging Market Economies' Sovereign Bond Spreads,” Bank of England Working Paper No. 205.

Ford, Robert, and Douglas Laxton, 1999, "World Public Debt and Real Interest Rate," Oxford Review of Economic Policy, Vol. 15, No. 2, pp. 77-94.

Fratianni, Michele and Franco Spinelli, 2001, "Fiscal Dominance and Money Growth in Italy: The Long Record," Explorations in Economic History, 38, pp. 252-72.

Ganapolsky, Eduardo J.J., and Sergio L. Schmukler, 2001, "Crisis Management in Argentina during the 1994-1995 Mexican Crisis: How Did Markets React?" in Devarajan, S., Rogers, F., and Squire, L. (eds.) World Bank Economists' Forum, No. 1, pp. 3-30.

Giavazzi, Francesco, 2003, "Inflation Targeting and the Fiscal Policy Regime: The Experience in Brazil," Bank of England Quarterly Bulletin, Autumn 2003; 43 (3). 
Greenspan, Alan, 2004a, "Testimony of Chairman Alan Greenspan," Economic outlook and current fiscal issues, Before the Committee on the Budget, U.S. House of Representatives.

Greenspan, Alan, 2004b, “Testimony of Chairman Alan Greenspan," Federal Reserve Board's semiannual Monetary Policy Report to the Congress, Before the Committee on Financial Services, U.S. House of Representatives.

Hemming, Richard, Michael Kell, and Axel Schimmelpfennig, 2003, "Fiscal Vulnerability and Financial Crises in Emerging Market Economies," IMF Occasional Paper No. 218, (Washington D.C., International Monetary Fund).

Hicks, J. R., 1952, The Social Framework, (Oxford University Press).

International Moneatary Fund, 2003, World Economic Outlook, September, (Washington D.C., International Monetary Fund).

—_, 2004, Global Financial Stability Report, April, (Washington D.C., International Monetary Fund).

Kamin, Steven B., and Karsten von Kleist, 1999, "The Evolution and Determinants of Emerging Market Credit Spread in the 1990s," BIS Working Paper No. 68, May, Basel, Bank for International Settlements.

Kaminsky, Graciela, and Sergio L. Schmukler, 1999, "What Triggers Market Jitters? A Chronicle of the Asian Crises," Journal of International Money and Finance, Vol. 18, pp. 537-60.

Kitchen, John, 1996, "Domestic and International Financial Market Responses to Federal Deficit Announcements," Journal of International Money and Finance, Vol. 15, No. 2, pp. 239-54.

Kopits, George, 2000, “How can Fiscal Policy help avert Currency Crises?” IMF Working Paper 00/185 (Washington: International Monetary Fund).

Koray, Faik, and Pingfai Chan, 1991, “Government Spending and the Exchange Rate,” Applied Economics, 23, September, pp. 1551-58.

Leeper, Eric, 1991, "Equilibria under Active and Passive Monetary Policies," Journal of Monetary Economics, 27, pp. 129-47.

Loyo, Eduardo, 1999, “Tight Money Paradox on the Loose: A Fiscalist Hyperinflation,” mimeo, J.F. Kennedy School of Government, Harvard University. 
Lucas, R. E., Jr., and Nancy L. Stokey, 1983, “Optimal Fiscal and Monetary Policy in an Economy without Capital," Journal of Monetary Economics, 12, pp. 55-93.

McCallum, Bennett T., 1997, "Issues in the Design of Monetary Policy Rules," NBER Working Paper No. 6016 (Cambridge, Massachusetts: National Bureau of Economic Research).

McMillin, W. Douglas, and Faik Koray, 1990, "Does Government Debt affect the Exchange Rate? An Empirical Analysis of the U.S. - Canadian Exchange Rate," Journal of Economics and Business, Vol. 42, November, pp. 279-88.

Melitz, Jacques, 1997, "Some Cross-country Evidence about Debt, Deficits and the Behavior of Monetary and Fiscal Authorities," CEPR Discussion paper No. 1653 (London: Center for Economic Policy Research).

— 2002, "Debt, Deficits and the Behavior of Monetary and Fiscal Authorities," in Marco Buti, Jürgen von Hagen, and Carlos Martinez-Mongay, The Behavior of Fiscal Authorities - Stabilization, Growth and Institutions, Palgrave, pp. 215-40.

Melvin, Michael, Don Schlagenhauf, and Ayhan Talu, 1989, "U.S. Budget Deficits and the Foreign Exchange Value of the Dollar", Review of Economics and Statistics, Vol. 71 (August) pp. 500-05.

Min, Hong G., 1998, “Determinants of Emerging Market Bond Spread: Do Economic Fundamentals Matter?” World Bank Policy Research Paper No. 1899.

Mundell, Robert A., 1960, "The Monetary Dynamics of International Adjustment Under Fixed and Flexible Exchange Rates"

Pesaran, Hashem H., and Yongcheol Shin, 1998, "Generalized Impulse Response Analysis in Linear Multivariate Models”, Economics Letters, Vol. 58, pp. 17-29.

Plosser, Charles I., 1987, "Fiscal Policy and the Term Structure," Journal of Monetary Economics, Vol. 20 No. 2, pp. 343-67.

— 1982, "Government Financing Decisions and Asset Returns," Journal of Monetary Economics, Vol. 9, pp. 325-52.

Rogoff, Kenneth, 2003, "Globalization and Global Disinflation,” Mimeo, International Monetary Fund.

Sargent, Thomas, and Neil Wallace, 1981, "Some Unpleasant Monetarist Arithmetic," Federal Reserve Bank of Minneapolis Quarterly Review, Fall, pp. 1-17.

Schmitt-Grohe, Stephanie, and Martin Uribe, 2000, "Price Level Determinacy and Monetary Policy under a Balanced-Budget Requirement," Journal of Monetary Economics, Vol. 45 No. 1, pp. 211-46. 
Sims, Christopher, 1994, "A Simple Model for Study of the Price Level and the Interaction of Monetary and Fiscal Policy," Economic Theory, 4, pp. 381-399.

— 1995, "Econometric Implications of the Government Budget Constraint," mimeo.

— 1997, "Fiscal Foundations of Price Stability in Open Economies," mimeo.

— 1998, “The Precarious Fiscal Foundations of EMU,” Mimeo.

Tanner, Evan, and Alberto Ramos, 2002, "Fiscal Sustainability and Monetary versus Fiscal Dominance: Evidence from Brazil, 1991-2000,” IMF Working Paper 02/5 (Washington: International Monetary Fund).

Taylor, John B., 1995, “Monetary Policy Implications of Greater Fiscal Discipline,” in Budget Deficits and Debt: Issues and Options, Federal Reserve Bank of Kansas, Kansas City, USA.

Uribe, Martin, and Vivian Z. Yue, 2003, "Country Spreads and Emerging Countries: Who Drives Whom?” NBER Working Paper No. 10018 (Cambridge, Massachusetts: National Bureau of Economic Research).

Wachtel, Paul, and John Young, 1987, "Deficit Announcements and Interest Rates," American Economic Review, Vol. 77 No. 5, pp. 1007-12.

Woodford, Michael, 1994, "Monetary Policy and Price Level Determinacy in a Cash-in-advance Economy," Economic Theory, 4:345-380.

_ 2000, "Fiscal Requirements for Price Stability," Journal of Money Credit and Banking, Vol. 33(3), pp 669-728.

Wyplosz, Charles, 1999, "Economic Policy Coordination in EMU: Strategies and Institutions," Mimeo.

Zoli, Edda, 2004, "Credit Rationing in Emerging Economies' Access to Global Capital Markets," IMF Working Paper 04/70 (Washington: International Monetary Fund).

_ 2005 , "How does Fiscal Policy affect Monetary Policy in Emerging Market Economies?" BIS Working Papers No. 174. 